\title{
Käsitused kasvatusest eesti vanasõnades ja kasvatusteaduses
}

\author{
Bianka Makoid \\ Peipsiääre vallavalitsuse haridus- ja kultuuriosakonna juhataja, \\ haridus- ja noorsootöö spetsialist \\ bianka.makoid@peipsivald.ee \\ Airi Liimets \\ Tallinna Ülikooli kasvatusfilosoofia külalisprofessor \\ airi_liimets@yahoo.de
}

\begin{abstract}
Teesid: Käesolevas artiklis oleme seadnud endale eesmärgiks välja selgitada, kuivõrd haakuvad eesti vanasõnades peituvad käsitused kasvatusest vastava kasvatusteadusliku mõttega Eestis. Vanasõnu käsitame kui argiteadvuslike kasvatuskäsituste allikaid. Empiiriliselt on uuritud 655 eesti vanasõna. Uurimismeetodiks on kvalitatiivsesse uurimisviisi kuuluv sisuanalüüs. Analüüsi tulemusena on vanasõnade sisus eristatud neli kasvatusmõtlemist väljendavat põhikategooriat (kasvatus ja kasvatamine, kasvatatav ja kasvaja, kasvataja, kasvatusmeetodid) ning 13 nende allkategooriat. Vanasõnade ja eesti vastava kasvatusteadusliku mõtte võrdlemisel selgub, et vanasõnade sisu haakub eelkõige biheivioristlikust mõtlemiskontekstist pärinevate kasvatuskäsitustega. Kõneldakse vanema ja lapse kasvatussuhtest, kus lapsel on allutatu positsioon. Kasvatust on valdavalt mõistetud kui lapse arengu juhtimist, kusjuures pojad on perekonnas eelistatumas seisundis. Ülekaalus on lapsevanemate võimu toetavad kasvatusmeetodid, sh kehaline karistamine.
\end{abstract}

Märksõnad: argiteadvusliku ja teadusliku võrdlus, Eesti, kasvatusteaduslik mõte, kvalitatiivne sisuanalüüs, käsitused kasvatusest, vanasõnad

\section{Sissejuhatus}

Kasvatus kui fenomen ja konstrukt on loomult ajastu- ja kultuurispetsiifiline. See tähendab, et kasvatus pole sisult ja vormilt muutumatu ei fenomenina sotsiaal-kultuurilises tegelikkuses ega ka konstruktina mõtlemises. Samas on kasvatuse teatud tähendused ja sisud väga "elujõulised", muutunud lausa stereotüpiseerunud normideks, mis kanduvad märkamatult edasi põlvest põlve. Lapsevanemad saavad oma teadmised selle kohta, kuidas kasvatada, eelkõige tahtmatult igapäevaelu käigus kodusest kasvatuskultuurist, oma vanematelt ning vanavanematelt. Näiteks kasvatusteadlane Jüri Orn (1998: 16) nimetabki 
selliste implitsiitsete teadmiste päritolukontekstina kodust kasvatuskultuuri. Ka professionaalne kasvatusteadlane ei mõtle kodus oma lapsi kasvatades enamasti õpitud kasvatusteaduslikele teooriatele, vaid toimib ja kasvatab nii, nagu ta on kogenud, kuidas on elus kunagi igapäevaselt kasvatatud teda ennast. Kasvatusfilosoofi Airi Liimetsa (2009: 386) järgi võib käsitused kasvatusest jaotada laias laastus kolme rühma: a) argiteadvuslikud, b) teaduslikud, c) filosoofilised. Käesolevas artiklis tulevad nimetatutest vaatluse alla esimesed kaks. Selle peamiseks põhjuseks on empiirilise uurimistöö tulemusel selgunu, et vanasõnades ei sisaldu filosoofilistele kasvatuse määratlustele iseloomulikke tähendusi.

Uuritavaks materjaliks antud artiklis ongi eesti vanasõnad kui argitarkuse väljendused (vrd Krikmann 1997). Vanasõnade uurimises näeme võimalust mõista eespool nimetatud argiteadvuslikke, implitsiitseid käsitusi kasvatusest, mis seostuvad valdavalt koduse kasvatuskultuuriga. Vanasõnad ei kuulu aga ainult minevikku ja üsna suletud perekondlikku elusfääri. Mõjuvõimsate kõnekujunditena ringlevad need ka tänapäeval nii meie suulises kõnes kui kirjalikus argikeeles, neid kasutatakse meedias ja reklaamitööstuses. Kasvatusteaduslik mõtlemine ja inimeste argiarusaamad kasvatusest ei pruugi aga alati ühtida. Sellest tulenevalt on meie eesmärk välja selgitada, kuivõrd haakuvad eesti vanasõnades peituvad käsitused kasvatusest vastava kasvatusteadusliku mõttega Eestis.

Hoolimata vanasõnade uurimise pikast traditsioonist Eestis on nende käsitlus kasvatusteaduslikust vaatenurgast jäänud senini üksnes üliõpilastööde tasemele. On uuritud vanasõnade kasutamist emakeele ja teise keele õpetamisel eri kooliastmetes (vt Kõiv 2011; Kask 2013; Cowan 2019). Vanasõnu on käsitletud osana pärimuskultuurist alushariduse valdkonna väärtuskasvatuses (vt Mitt 2012; Aruste 2014), on uuritud laste suutlikkust mõista vanasõnu (Teras 2019). Kasvatuse tähenduste aspektist on vanasõnu uuritud teiste rahvaste vanasõnadele tuginedes (nt Palacios 1996; Volkov 1999), kuid Eestis põhjalikumad vanasõnakäsitlused sellest aspektist senini puuduvad.

Endile seatud eesmärgini jõudmiseks käsitleme kõigepealt artikli esimeses osas lühidalt seda, mida kujutab endast vanasõna kui folkloorižanr ja argitarkuse väljendaja. Teises osas vaatleme empiirilisele uurimistööle tuginedes, kas ja kuidas on võimalik semantiliselt kategoriseerida ja piiritleda vanasõnu nende sisus peituvatest kasvatuslikest tähendustest lähtudes. Artikli kolmandas osas selgub, kuidas haakuvad omavahel käsitused kasvatusest eesti vanasõnades kui argiteadvuslik tarkus ja vastav teaduslik mõte eesti kasvatusteaduses. Antud võrdlust silmas pidades on kõigepealt lühidalt nimetatud eesti kasvatusteaduses viimase $c a 70$ aasta vältel käibelolnud teaduslikud käsitused 
kasvatusest, kuid artikli piiratud mahu tõttu on põhjalikumalt vaadeldud vaid neid teaduslikke mõtteid, mis haakuvad empiiriast koorunud sisudega. Vähesel määral leiab osutusi kasvatusteaduslikule mõtteloole juba artikli teises osas ehk vanasõnade empiirilise uurimise tulemuste esitluses.

\section{Vanasõnad kui argiteadvuslike kasvatuskäsituste allikas}

\subsection{Vanasõna kui folkloorižanr}

Argiteadvuses pikka aega püsinud arusaamad ja uskumused peituvad eeldatavasti juba rahvaluules (nt vanasõnades, kõnekäändudes jm), väljendades kontsentreeritud kujul argiteadmist (Liimets 1999: 23; Hirsjärvi \& Huttunen 2005: 14, 125). Sirkka Hirsjärvi ja Jouko Huttunen (2005: 125) näiteks rõhutavad, et Soome kasvatustraditsioonis on vanasõnadel olnud alati oluline koht, sest nende tarkuseterade toel on ühiskonnas säilitatud traditsioone põlvest põlve. Sama võiks ju eeldada ka Eesti kasvatustraditsiooni kohta.

Näiteks Edda Kaimre ja Inger Kraav (1998: 131-139; Kaimre 2000: 6-10) on uurinud kolme põlvkonna arusaamu ja uskumusi kasvatusest, et saada ettekujutust kasvatustegelikkusest Eesti perekondades. Uuringust ilmnesid nii traditsioonilised kui ka ühiskonnas kaasaja arengutendentsidest tulenevad arusaamad. Põlvkondade vahel tekivad erimeelsused ranguse, moraali, isikuvabaduste piiramise ja karistamise osas. Vanavanemad aktsepteerivad kehalist karistamist kasvatusmeetodina näiteks põhjendusega, et see laps läheb metsa, kes vitsa pole õigel ajal saanud. Kasvatuspõhimõtetes on kõige vanemale põlvkonnale oluline ausus, kuulekus, autoritaarsus, kohustused, töö, õppimine; keskmine põlvkond rõhutab hea otsustusvõimelise inimese kasvatamist ja hea hariduse võimaldamist, häid suhteid; noorimad tähtsustavad sõbralikke suhteid, armastust ja turvalisust, iseseisvust ning individuaalsust. Näiteks vanema põlvkonna arvates hoolitseb hea ema kodu, toidu ja laste eest, on range ja nõudlik, töökas. Ideaalisa peab olema perepea, autoriteet ja eeskuju, hoolitsema majanduslikult oma pere eest ja tegelema ka lastega. Uurimuse tulemustes on nimetatud ka vanasõnu, mida kasvatuspõhimõtetega seostatakse. Uurijate arvates on see mõistetav, sest rahvatarkusi väljendavad vanasõnad ongi olnud rahvapedagoogika sisuks, nende tõdede varal lapsi kasvatatigi. Paljud vanasõnad on veel tänini kõigis sugupõlvedes kasutusel: nt väiksed lapsed, väiksed mured, suured lapsed, suured mured; mis noorelt õpitud, see vanas eas meeles; virgad vanemad, viksid lapsed; laps räägib siis, kui kana pissib; mida armsam 
laps, seda valusam vits; käbi ei kuku kännust kaugele jne (Kaimre \& Kraav 1998: 136-138). Seega mõtestatakse vanasõnade kui argitarkuse abil ka oma kasvatusarusaamu.

Folkloori nähakse kui teatud sotsiaalse rühma kultuurilise identiteedi kandjat ja sotsiaalse ühtekuuluvustunde loojat (Dundes 2002; Honko 1998). Clifford Geertz (2003: 99-113) selgitab argitarkuse olemust, tuginedes nn primitiivrahvaste uurimisele. Argi- ehk rahvatarkus põhineb tema järgi nii eelarvamustest kantud uskumustel kui ka hinnatud kogemustel, millega on elus hakkama saadud ja kuidas on lahendatud igapäevaseid probleeme. Sihiks on püüd muuta maailm selgepiirilisemaks, leida probleemidele lahendusi ning olla olukorra peremees. Argitarkusel on rahvalik-filosoofiline taust, mis manitseb mõistlikkusele, ettevaatlikkusele, arukusele jne. Elu mitmekesisusest, ebajärjekindlusest, vastuolulisusest tulenev argitarkus vormub epigrammideks, vanasõnadeks jne.

Etümoloogiliselt annavad rahvapärased terminid vanasõnade ja ka kõnekäändude kohta eri keeltes erinevaid tähendusvarjundeid: vana sõna, ütlus, räägitud sõna, korduv sõna või ütlus, igapäevane sõna, rahvatarkus, tark sõna jne. Seega kajastuvad juba rahvapärastes väljendites žanrile iseloomulikud tunnused (Krikmann 1997: 13-14). Rohketes vanasõna definitsioonides on esile tõstetud erinevaid tahke, eesmärgiga eristada vanasõna muudest lausungitest. Vanasõnauurija Archer Taylori (1931: 3) arvates on vanasõna žanri lõplik määratlemine võimatu, kuid saab välja tuua mingi sõnulseletamatu kvaliteedi, mis eristab vanasõna teistest lausetest - need on rahva seas käibelolevad ütlused.

Eesti tuntuim parömioloog Arvo Krikmann (1997: 20, 52) on ka teiste vanasõnauurijate definitsioone arvesse võttes tõstnud esile järgmised olulised tunnused: vanasõna on traditsiooniline, lühike, didaktilise sisu ja poeetilise vormiga, tabavalt ja kujundlikult sõnastatud üldistav väide, imperatiiv või hinnang - seega mingi seaduspärasuse või normi formuleering. Rahvusvaheliselt tunnustatud vanasõnade uurija Wolfgang Mieder (2004: 3) toob esile järgmised vanasõna tunnused: vanasõna on rahva seas üldiselt tuntud lühike lausung, mis sisaldab tarkust, tõde, moraali ja traditsioonilisi vaateid kujundlikus sõnastuses ning meeldejäävas vormis.

Vanasõnade kui selliste juured ulatuvad antiikaega, olles esindatud piiblis, grammatikates, sõnaraamatutes, lugemikes, ajakirjanduses jm. Kõige varasemad trükis ilmunud eesti vanasõnad on pärit 17. sajandist. 1660. aastal ilmunud Heinrich Gösekeni grammatikas "Manuductio ad Linguam Oesthonicam" oli umbes 70 eestikeelset vanasõna. Järgnesid Anton Thor Helle ja August Wilhelm Hupeli grammatikad, milles vanasõnade osakaal oli juba märksa suurem (Hussar et al. 1984). 19. sajandil algas Eestis vanasõnade sihipärane kogumine, mille tulemusi kajastavad Eesti Kirjandusmuuseumi rahvaluulekogud. Tänapäevani kestva pikaaegse kogumistöö tulemusena on muuseumi käsikirjalistes 
rahvaluulekogudes üle 160000 vanasõna (vt Normann 1955: 30-36; Hussar et al. 1984: 25-30). Võrreldes teiste folkloorižanridega on vanasõnade vastu olnud huvi suurem nende didaktilisuse ja retoorilisuse tõttu ning neid on palju kasutatud sõnaraamatutes ja koolikirjanduses. Kõige mahukamad vanasõnade trükised on käsikirjaliste materjalide, trükistes ilmunu ja vanasõnade koondkartoteegi põhjal aastail 1980-1988 koostatud akadeemiline väljaanne "Eesti vanasõnad I-V" ning rahvaväljaandena mõeldud 1984. aastal ilmunud "Vanasõnaraamat" (Hussar et al. 1984: 31-32).

Ühel vanasõnal võib olla palju eri variante ja sõnastusi, kuid ühe dominantse sõnastusvormi järgi on jagatud vanasõnad tüüpideks, s.t vormilt, sisult ja funktsioonilt piisavalt sarnaste tekstide kogumiks (akadeemilises väljaandes on kokku 15140 tüüpi) (Krikmann 1997: 156). Krikmann (ibid.: 173-175) toob esile sada kõige tuntumat vanasõnatüüpi, mille kohta on arhiivis kõige enam üleskirjutisi. Edetabeli kuus esimest (välja jäetud on kalendaarsed vanasõnad) on järgmised:

1. Kelle jalg tatsub, selle suu matsub

360

2. Kes koera saba kergitab, kui koer ise

360

3. Varane pühib nokka, hiline saputab tiibu $\quad 310$

4. Pill tuleb pika ilu peale $\quad 290$

5. Suur tükk ajab suu lõhki 285

6. Käbi ei kuku kännust kaugele 285

Olgu öeldud, et nendest vanasõna käbi ei kuku kännust kaugele edastab otseselt kasvatuslikku sõnumit, rõhutades eeskuju olulisust. Need edetabeli tipus olevad vanasõnad on tuntud ka teiste rahvaste seas. Soome vanasõnauurija Matti Kuusi (Hussar et al. 1984: 7-10) on võrrelnud ja klassifitseerinud eri rahvaste vanasõnu ning leidnud seaduspära: rahvusvaheliselt tuntud vanasõnad on populaarsed ka iga üksiku rahva juures.

Arvo Krikmann (1997) on hinnanud arhiivis leiduvate tekstide autentsust. Vanasõnad, mille autentsus on kaheldav, on jäetud arvestusest välja. Seega on arhiivitekstide tegelik arv veelgi suurem, samuti tekib vanasõnu tänapäeval pidevalt juurde (vrd Granbom-Herranen et al. 2015; Voolaid 2020). Krikmann viitab Zipfi reeglile ehk Zipfi kõverale, mis näitab vanasõnade sagedusjaotuse universaalsust nii tüübi-, tekstihulkade kui ka geograafilise leviku lõikes. Zipfi kõvera järgi on kõige rohkem ühe tekstiga esindatud tüüpe (tüüpide arv 7245 ehk koguhulgast 57\%), edasi ilmneb järsk vähenemine (1-5 variandiga $83 \%$ ). Skaala teises otsas on üliproduktiivsed suurtüübid. Krikmann (1997: 187-193) näeb probleemi üheainsa kirjapanekuga tekstide puhul: kas see on kellegi improvisatsioon või oligi see väga kitsa levikuga vanasõna. Andmete kogumisel oma uurimistöö jaoks me vanasõnade tekstide arvu tüübis arvesse ei võtnud. Meie valimis leidub ka ühe tekstinäitega vanasõnu. 
Vanasõnades avalduvat maailmapilti avab Arvo Krikmann (1997: 260-261) oma teoses "Sissevaateid folkloori lühivormidesse I". Vanasõnu käsitab ta rahvapärase filosoofia ilminguna, argise maailmavaate väljendusena, mis arvatavasti just suulise käibe tõttu sisaldab palju vasturääkivusi ja paradokse. Vanasõnad ei anna vastuseid tähtsatele filosoofilistele küsimustele, mis on maailm, mis on algus ja lõpp, mis on aeg ja ruum, kas jumal on olemas jne. Ilmselt seetõttu ei haakunud ka meie uuritud vanasõnade sisu filosoofiliste käsitustega kasvatusest. Vanasõna lähtub konkreetsest argisest elupraktikast. Vanasõna põhiülesanne on kujundada inimeste suhtumisi ja käitumist, suunata argielu. Vanasõnad kuuluvad retoorilis-folkloorse žanri hulka, neid kasutatakse igapäevases suhtluses, s.h pedagoogilises kõnes (Voolaid 2011; Granbom-Herranen 2012). Igasuguse kommunikatsiooni siht on alati mõjutada suhtluspartneri käitumist. Vanasõnade abil saab teha seda mitmel viisil: käskida, keelata, soovitada, hoiatada, esitada üldkehtivaid tõdemusi, millest saab välja lugeda hinnanguid ja tuletada ettekirjutusi (Krikmann 1997: 15-22). Risto Järv (1997) rõhutab Matti Kuusile ja Alan Dundesele toetudes vanasõna kui argiarvamuse autoriteetsust. Vanasõna kasutaja ei esita millegi kohta oma seisukohta, vaid edastab anonüümset traditsioonilist rahvapärimust, lisades sellega öeldule väärtust ja mõjuvust.

Eri rahvaste vanasõnades esinevad sarnased üldinimlikud teemad. Vanasõnades on oluline koht maaelul ja loodusel, aga kõige enam annavad vanasõnad siiski aimu suhetesfäärist ja kõlblusteadvusest. Vanasõnade juures võib eri rahvaste folklooris täheldada teatavat maailmatajumise ehk elutunnetuse ühtsust (Krikmann 1997: 262-263). Vanasõnad on nii üldarusaamadelt kui ka teemade poolest antropotsentristlikud. Kui tuua esile eri rahvaste vanasõnadele iseloomulik, võib öelda, et: 1) vanasõnade maailm on üsna kitsas; 2) esitatakse iseseisvaid seisukohti teoreetiliste õpetuste (nt filosoofia, eetika, religioon) mõjutusteta; 3) vanasõna annab maailmanägemisele egotsentristliku kvaliteedi, mis on alalhoidlik, konservatiivne, pessimistlik, peegeldades peamiselt vaese inimese tõekspidamisi; 4) vanasõnades peegelduvad üsna rasked sotsiaalsed ja majanduslikud olud (ibid.: 263). Vanasõna annab maailmaga suhtlemiseks lihtsad ja selged üldarusaamad: a) maailm on vaenulik ja elus on kaugelt rohkem halba kui head; b) inimene (eriti üksikisik) on selle kurjuse vastu jõuetu; c) töö ja vaev on paratamatud; d) kuidas sina teistega, nõnda teised sinuga (ibid.: 264). Nendest juhistest lähtuvalt saab vanasõnadest tuletada ka ellusuhtumise, kus taunitakse laiskust ja rumalust, peetakse vooruseks virkust ja tarkust, ettevaatlikkust; manitsetakse mõõdukusele ja alalhoidlikkusele, eelistatakse tervist ja tarkust varale jne. Vanasõnades kajastuvaid vastandlikke arusaamu saab seletada aga elu enda mitmekesisuse ja vastuolulisusega. Archer Taylori 
(1931: 168-169) arvates on vanasõnade filosoofia üldinimlik ja nende eetika rajaneb kesktee põhimõttel, mis on markeeritud vasturääkivustega.

Enamik eesti vanasõnadest väljendab feodalismiaegse talupoja maailmanägemist, mõttelaadi ja kogemusi (Hussar et al. 1984: 12), ent käibelt pole nad päriselt kadunud. Wolfgang Mieder (2004) arvab, et väljasuremisoht vanasõnu ei ähvarda, nende kasutusala on endiselt lai nii suulises kõnes kui ka kirjalikes tekstides. Aja möödudes siiski osa vanasõnadest unustatakse. Taylor (1931: 33) on nimetanud vanasõnade käibelt kadumise põhjuseid: moraalireeglil pole enam tähtsust, metafooril puudub kogemustaust või sümbol on kaotanud oma tähenduse. Nii ongi vanasõnade repertuaar pidevas muutumises. Vanasõnad, mis tänapäeva inimest ei kõneta, kaovad kasutusest, asemele tulevad uued, mis peaksid kajastama paremini kaasaja kombeid ja arusaamu (Mieder 2004: 146-148). Vanasõna populaarsust tõestavad ka tänapäevases žanris esitatavad vanasõnaparoodiad (Baran 2010a). Seega väitega, et vanasõnad on iganenud ja unustatud rahvaluuležanr (Hussar et al. 1984: 10-11), ei saa nõustuda. Seda tõestavad ka teised tänapäevased folkloorialased uurimused (nt Voolaid $2011 ; 2020)$.

\subsection{Varasemaid uuringuid kasvatusega seotud vanasõnadest}

Vanasõnad on ka tänapäeva ühiskonnas oluline kasvatusvahend, eriti perekonnas, lasteaias ja koolis. Vanasõnade abil saab õpetada moraalseid väärtusi ja sotsiaalseid oskusi, anda edasi teadmisi inimesest ja maailmast laiemalt. Emakeele ja võõrkeele õpetamisel saab vanasõnade kaudu edastada kultuuritraditsioone ja moraalijuhiseid (Mieder 2004: 146-148). Eestis on uuritud vanasõnade esinemust õpikutes ning kasutamist õppe- ja kasvatustöös koolis ning lasteaias (nt Kask 2013; Aruste 2014; Voolaid 2011). Lasteaiapärimuse kogumisest kokkuvõtet tehes tõdeb Piret Voolaid (2011), et õpetajad kasutavad vanasõnu väga laialdaselt, sisendades nende abil positiivseid väärtusi. Õpetajate kasutuses olevatest vanasõnadest olid kõige populaarsemad: pill tuleb pika ilu peale; töö kiidab tegijat; tee tööd töö ajal, räägi juttu jutu ajal; enne mõtle, siis ütle; harjutamine teeb meistriks; kes kannatab, see kaua elab; kus viga näed laita, seal tule ja aita; targem annab järele.

Soome kasvatusteadlase ja vanasõnauurija Liisa Granbom-Herraneni (2012) väitel on ka Soome teadlased otsinud vanasõnadest vastuseid küsimustele, kuidas ja miks last kasvatati. Jesus Palacios (1996) on võrrelnud eri rahvaste vanasõnu ning ta nimetab viit kõigile rahvastele ühist teemat: pere ja laste tähtsus, laste iseloomujooned, pärilikkus, kogemuste osatähtsus, distsipliin 
ja pingutus. Vanasõnades väljenduvad enamasti agraarühiskonna traditsioonilised arusaamad: autoritaarsus, kuulekus, distsipliin, karistamine, soolised stereotüübid, lapse kaasasündinud iseloomujooned jne.

Dumitru Stanciu (1986) on uurinud rumeenia vanasõnades kajastuvaid kasvatusprobleeme. Tema järgi tegelevad vanasõnad lapse arenguga: mis on lapsele kaasa sündinud, mis on kasvatuse ning õppimise teel omandatav, milline aeg on õppimiseks kõige efektiivsem. Vanasõnad ütlevad, et vanematest sõltub väga palju, et nooruses omandatakse kõike kiiremini, et õppimine kestab kogu elu. Rahvatarkuses hinnatakse kõrgelt mõistust ja tarkust, mis kaalub üle materiaalsed väärtused. Vanasõnad näitavad ka õpetajatele, mida nad peaksid kasvatusaspektidest teadma. Õpetaja peab arvestama, et keegi pole täiuslik ning lapsed pole ühesugused. Vanasõnades on vähe positiivset motiveerimist, hoopis negatiivsed kogemused, ebaõnnestumised ja kannatused arvatakse olevat palju paremaks õppimise allikaks. Stanciu arvates saab nii põhjendada ka vanasõnades laialt levinud kehalise karistamise mõtet. Rahvatarkus on pragmaatiline, eesmärkide saavutamist peetakse olulisemaks kui selleks kasutatavaid vahendeid. Kasvatust mõistetakse just vanema ja lapse suhte kaudu, mis tähendab erinevat tüüpi kohustusi ja vastastikust mõjutamist. Laste karistamine ei näita pedagoogika puudumist, vaid vanemate kiindumust ja laste tuleviku eest hoolitsemist. Nagu käesolevast artiklist selgub, on paljuski samad teemad ja probleemid leitavad ka meie analüüsitud vanasõnadest.

Gennadi Volkov (1999: 62-78) analüüsib raamatus "Etnopedagoogika" vanasõnade ja teiste folkloorižanride pedagoogilist rolli elus. Vanasõnad kirjeldavad kasvatusliku mõjutamise vahendeid, annavad inimesele positiivseid või negatiivseid hinnanguid, kutsuvad üles eneseharimisele ja õppimisele. Vanasõnade kasvatuslikud ideed kajastavad Volkovi järgi järgmisi aspekte: laste pärilikkus ja sõltumine vanemate käitumisest, kasvatusmeetodid ja eesmärgid, töö- ja kõlbluskasvatus jm. Volkovi arvates näitavad vanasõnad, et iga inimene võib oma käitumist ja iseloomu parandada, tõusta alati veel ühe sammu võrra kõrgemale. Peamisena tuleb vanasõnades esile just moraalse kasvatuse ja kasvamise ülesanne. Volkovi arvates on vanasõnadesse sajandite jooksul kristalliseerunud üldsuse arvamus, antakse eetiline hinnang inimese käitumisele ja rahva elule üldiselt.

Palacios, Stanciu ja Volkov tõstavad vanasõnades esile sarnaseid kasvatuslikke aspekte, mida oleme meie täheldanud eesti vanasõnades tänu oma empiirilisele uurimistööle. 


\section{Vanasõnade empiiriline uurimine}

\subsection{Valim, uurimismetoodika ja analüüsiprotsessi kirjeldus}

Vanasõnakogu Eesti Kirjandusmuuseumis on väga mahukas, aga produktiivsuselt ebaühtlane. Kahetsusväärselt on varasemate üleskirjutuste juures arhiivimaterjalides vähe kontekstilisi kirjeldusi, sest kogumisel ei peetud seda omal ajal oluliseks. Rohkem saab vanasõnade tõlgendamise ja kasutamise kohta teada alates 1960.-1970. aastatel kogutud andmetest. Varasema materjali juures esineb situatsiooniselgitusi ja teavet vanasõnade tähenduste kohta süstemaatiliselt ainult üksikutelt korrespondentidelt-kogujatelt. Samas saab vanasõnade puhul rääkida siiski kvalitatiivselt parimast korrastatud ja tüpologiseeritud arhiivimaterjalist, mille süstematiseerimist alustati Eesti Kirjandusmuuseumis 1960. aastatel. Loodud vanasõnade tüpoloogilise koondkartoteegi alusel on publitseeritud akadeemiline väljaanne "Eesti vanasõnad I-V" (Krikmann \& Sarv 1980-1988) ning 1984. aasta rahvaväljaanne "Vanasõnaraamat" (Krikmann 1997: 5). Tänaseks on vanasõnaväljaannete põhjal loodud elektrooniline andmebaas, mida täiendatakse arhiiviandmetega (vanasõnatekstidele lisatakse detailsed andmed kogujate, kogumisaja ja arhiiviviidete kohta). Meie valim kajastab rahvaluulekogude andmestiku seisu enne 1980. aastaid, ka arvandmed tuginevad toonastele kogudele.

Valimisse andmete saamiseks kasutasime "Vanasõnaraamatut", teost "Eesti vanasõnad I-V" (15 140 vanasõnatüüpi), e-andmebaasi "Eesti ütlused. Vanasõnad" (kokku 13000 vanasõnatüüpi) ja Eesti Kirjandusmuuseumi parömioloogia töörühma rajatud paberkartoteeki (sisaldab peamiselt Eesti Rahvaluule Arhiivi kogudest, Keele ja Kirjanduse Instituudi murdekogust ja erinevatest trükistest pärinevaid vanasõnu, ühtekokku 160000 teksti), kust sai lisamaterjalina selgitusi vanasõnade tõlgendamise ja kasutamise kohta.

Valimis on kokku 655 vanasõna, mis otseselt viitavad lapsele, kasvamisele, kasvatamisele ja lapsevanematele ning kasvatusmeetoditele. On aga ka vanasõnu, mis konkreetse eaga pole määratletud, kuid sisuliselt sobivad andmestikku. Uurimismaterjali pidi vanasõnade ääretu rohkuse tõttu piiritlema ja tegema valiku. Andmestikuna kasutasime vanasõnatüüpide normaalvorme. Töömahukuse tõttu ei vaadelnud me suurearvuliste vanasõnatüüpide variantide sõnastuses esineda võivaid uusi tähendusnüansse. Valimiks on kõik sobiva sisuga vanasõnad, vaatamata nende tekstide arvule. Nii on valimis vaid ühe variandiga, kuid ka väga produktiivseid vanasõnu (nt vääna vitsa, kuni vits väändub - 205 varianti). Enamik valitud vanasõnadest on siiski väikese variantide arvuga. Andmestikku valitud kõiki vanasõnu kategooriate kaupa liigendatuna ning ühe koondtabelina, kust oleks näha ka iga vanasõna tüübinumber ja 
selle variantide arv, me käesolevale artiklile seatud mahu tõttu esitada ei saa (ka artikli lisana mitte). Valimi arvandmed pärinevad peamiselt e-andmebaasist. Arhiivis võib variantide arv olla suurem, sest e-andmebaasi lisati üksnes autentseks loetud vanasõnavariantide arvud ja uuemad matejalid seal samuti ei kajastu. Tänapäeval ei ole rahvaluule autentsus folkloristikas enam küsimuseks, kuid teaduskirjanduses on alati olnud probleemiks, milline ütlus on ikka vanasõna ja milline mitte (vrd Krikmann 1997; Granbom-Herranen 2012; Mieder 2004). Kuna valimi aluseks on arhiivimaterjalid, lähtusime arusaamast, et kõik raamatus, andmebaasis ja kartoteegis olevad lausungid on vanasõnad.

Meie uurimistöö kuulub hermeneutilis-fenomenoloogilisse mõttesuunda ning metodoloogiliselt esindab kvalitatiivse uurimisviisi raamesse kuuluvat sisuanalüüsi. Kvalitatiivset sisuanalüüsi (Laherand 2008; Lagerspetz 2017) rakendatakse tekstiandmete sisu subjektiivseks tõlgendamiseks süstemaatilise liigendamis- ja kodeerimisprotsessi ning teemade või mustrite kindlakstegemise abil. Materjali seesmise loogikani ning selles esinevate mustriteni jõutakse alles analüüsi käigus, saades tulemuseks kirjeldava struktuuri. Antud meetodi (Schreier 2012: 59-63) abil valitakse materjalist välja teatud põhiaspektid ja keskendutakse neile. Seega kodeerimisraamistiku põhikategooriad on aspektid, millele soovitakse analüüsis keskenduda. Uurijad ise otsustavad kodeerimisraamistiku struktuuri ja põhikategooriate üle.

Kvalitatiivse analüüsi ühikud olid laused ehk vanasõnad. Andmete analüüsimisel kasutasime induktiivset ja deduktiivset lähenemist kombineeritult. Kategooriad moodustasime andmestikust lähtuvalt, toetudes oma kasvatusteaduslikele teadmistele. Analüüsi esimeses etapis lugesime andmed üle, kodeerisime ja jagasime tähenduste alusel gruppidesse. Seejärel määratlesime esmased kategooriad ja lugesime veel kord andmed üle, siis ühendasime mõned kategooriad üheks suuremaks põhikategooriaks. Vanasõnade kategoriseerimist raskendas nende kujundlik keel ja sellest tulenev mitmetähenduslikkus. Osade vanasõnade puhul pidi otsustama, millise kategooria alla see panna, sest ühes vanasõnas võivad olla ühendatud vastandlikud arusaamad. Mõned ebaselge tähendussisuga vanasõnad jäidki kategoriseerimisest välja. Analüüsi jaoks selgema süsteemi loomiseks koostasime ülevaatliku kategooriate skeemi (vt joonis 1).

Töö käigus kujunes välja neli põhikategooriat, milledest igaühel on ka allkategooriad. Esitatud näidetele on lisatud teadusliku väljaande (teose "Eesti vanasõnad I-V" = EV) tüübinumbrid. Välja on toodud ka mõnede vanasõnade tekstinäidete arv, kui see on esile tõstmiseks piisavalt suur või tõlgendamisel vajalik (rohkem kui 25 varianti). Rohkearvuliste vanasõnatüüpide tõlgendamisel oleme kasutanud ka arhiivist saadud kontekstinäiteid. Väikesearvuliste vanasõnade puhul tavaliselt kontekst puudus. Valiidsuse tagamiseks lisasime kontekstinäidete juurde ka täpsed allikaviited (koht, isikunimi, aastaarv). 


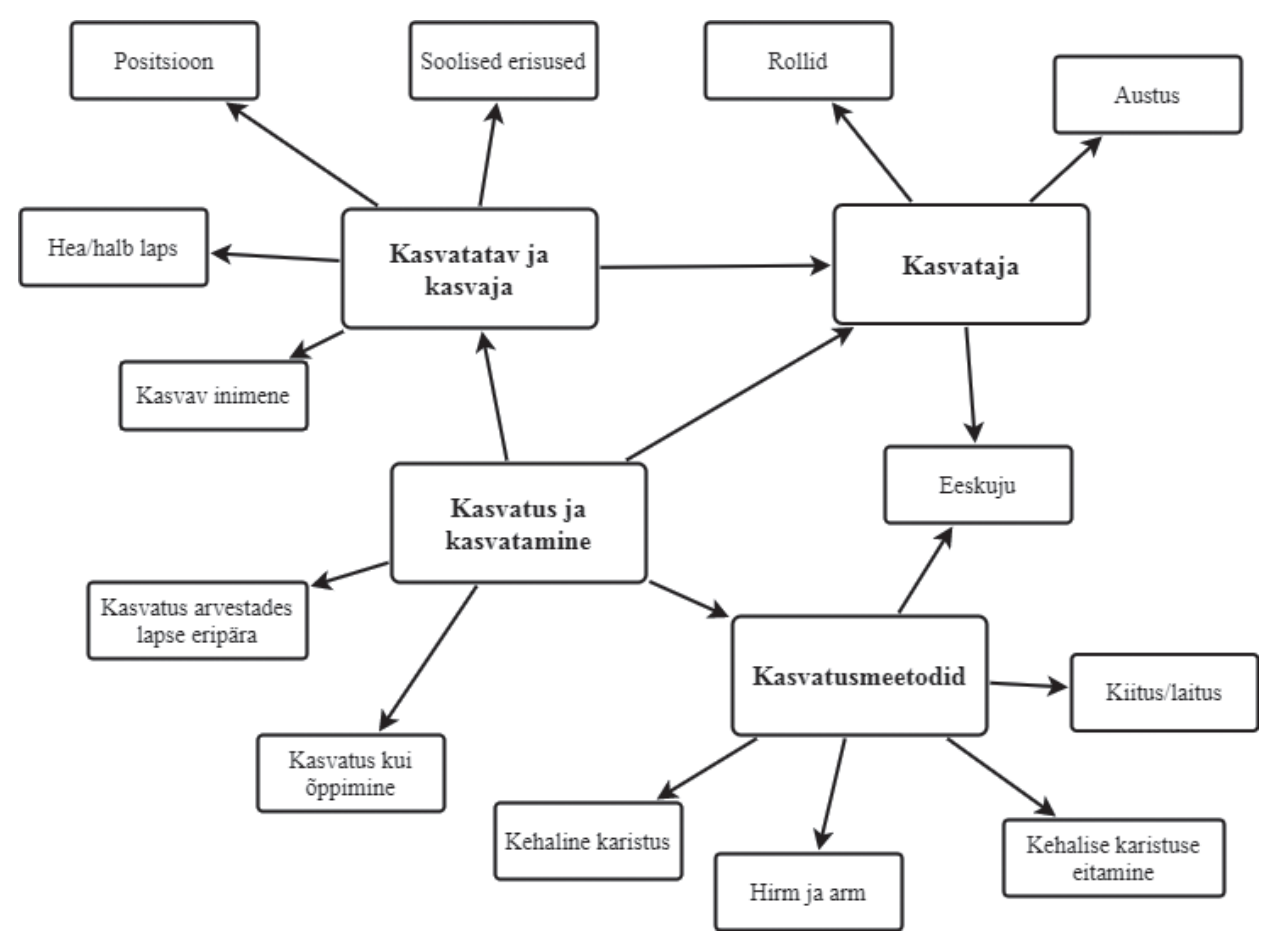

Joonis 1. Kategooriatena esitatud vanasõnades leiduvad kasvatuslikud fenomenid.

\subsection{Kasvatuslikud fenomenid vanasõnades}

Andmeanalüüsi tulemused esitame järgnevalt joonisel 1 toodud sisukategooriate (neli põhikategooriat ja nende allkategooriad) kaupa, sealjuures neid veelgi enam diferentseerides.

\section{PÕHIKATEGOORIA: Kasvatus ja kasvatamine}

Kasvatuse kui tervikliku konstrukti koostisse kuuluvad nii kasvatamine kui ka kasvamine. Kasvatussuhtes on osalised nii kasvataja kui kasvatatav, kes mõjutavad teineteist kasvatusprotsessis. Kasvatust määratlevad nii selle kaudu taotletavad eesmärgid kui ka nende saavutamiseks valitud kasvatusviisid ja -meetodid. Otseselt esimese põhikategooria alla paigutame aga tinglikult vaid kasvatamisega seonduva. 
a) Allkategooria: Lapse eripära arvestav kasvatamine

Vanasõnades nenditakse, et laste kasvatamine on keeruline ja vaevanõudev tegevus.

Kui lapsele sõrm antakse, siis tahab ta tervet kätt (EV 5460).

Kui laps majas, peab üheksa silma ühe asemel olema (EV 5461).

Lapsõtegemine mte põlõ kun'ts, aga lapsõ kasvatamine ond kun'ts (EV 5581).

Kergem on põldu künda kui lapsi kasvatada (EV 9141).

Vanasõnade järgi nõuavad lapsed täit tähelepanu. Lapse soovidega tuleb arvestada ning ta tahtmisi täita, kuid hoiatatakse sellega piiri pidama. Samas peetakse kasvatust ka kunstiks. Osutatakse, et kasvatamisel võib kergesti midagi valesti minna ja halva kasvatuse tagajärgi on raske parandada.

Kasvata hagijast, kasvata kailaisandaks (EV 3441).

Kes nõest kasvatab, see käed kõrvetab (EV 7621).

Puu satas ika sinnä, kohe tahetas laske (EV 9109).

Vanasõnad annavad nõu, millal on õige aeg last kasvatada. Lapsel on õpetusest ja karistusest kasu, teda on veel võimalik mõjutada ja suunata. Kui õige aeg mööda lastakse, siis pole enam midagi teha.

Painuta noorelt poja selga (EV 8263).

Sis pessä' last, ko riste om pingi pääl; ko piuta om pingi pääl, sis inäp pesku-ui' (EV 8529).

Vääna vitsa, kui vits väändib (EV 14264, 205 varianti).

Õienda puud täna (EV 14546).

Vanasõna vääna vitsa, kui vits väändib suur tekstihulk tõestab teadmise last tuleb maast madalast õpetada ja ka vajadusel karistada - laia levikut ja populaarsust. Kontekst näitab vanasõna mitut kasutusvõimalust. Ühelt poolt väljendab see kasvataja usku võimalusse kasvatuse teel lapse iseloomu ja käitumist suunata, probleeme ennetada, sõnakuulmatut last korrale kutsuda ning õigele teele juhatada: "Õigel aal piab lapse pahad teud ää keelma. Piab silma pial hoidma, et mitte hillas jääda. Pärast saa änam õpitud vigusid kua välla” (Hanila, I. Aavekukk, 1971). Teiselt poolt on vanasõna tarvitatud ka halva kasvatuse või hoopis õpetamata jätmise tagajärje retoorilise nentimisena: "Ütled inimese kohta, et kui vanass lähäb, mes sa viil vanale tiid. Kui nuur, siis suad opata" (Kodavere, A. Univere, 1939). Kui muidu on vanasõnades vits karistuse sünonüüm, siis siin on sel sõnal uus tähendus, väljendades last või noort inimest.

Arutleda võib selle üle, millist lapse kasvatusviisi siin silmas peetakse. Tegevustena esinevad painutama, väänama ja õiendama väljendavad pigem jõupositsioonilt sihipärast sekkumist, mis võib olla nii verbaalne kui ka 
füüsiline. Vanasõna sis pessä' last, ko riste om pingi pääl; ko piuta om pingi pääl, sis inäp pesku-ui’ osutab kehalisele karistamisele ka otseselt. Selle vanasõna kontekst näitab, et õigete kasvatusmeetodite valiku üle otsustamine on üsna ebamäärane: "Last võib siis veel peksta, kui ta magab sängis põigiti, kuid kui ta juba magab sängis pikuti, siis enam last peksta ei saa, siis ta on selleks liiga vana" (Krasnodari krai, J. Olev, 1969).

Kasvatamise vajalikkuse rõhutamise kõrval hoiatatakse vanasõnades liiga tugeva jõu ja sunni kasutamise eest.

Liig kõverdamine toob murdmist (EV 4908).

Kui looka liig kokku tõmmatakse, siis peab ta viimaks praksatama (EV 6024).

Enne paendub, pärast murdub (EV 8261).

Vanasõnad ei anna täpset juhist, kus on piir, milleni võib lapsevanem oma suunamisega minna. Küsimuseks jääb ka, kuidas peaks iseloomult erinevate lastega toimima. Vanasõnad ütlevad, et lapsele on vanemate suunamist ja mõjutamist tulevikus hakkamasaamiseks vaja.

Ei painduv puu naljalt murdu (EV 8260).

Kust üks hea puu tahab sünnitada, see annab ennast painutada (EV 9092).

Tallitsemäta hobu ei seisä tallin (EV 11495).

Kasvatus on eluaegne protsess, kus kasvatatav peaks jõudma järjepideva enesekasvatuseni. See saab toimuda siis, kui laps selleks valmis on.

Lapsed on linnud: saavad suled selga, ongi läinud (EV 5487).

Vigaks siis lenda, kui suured suled seljas (EV 5747).

Kindlasti ei ole vanasõnades üheselt määratletud, mis see on, mida vanemad peaksid oma lastele eluks kaasa andma. Iga vanem teeb seda oma parema arusaamise ja äranägemise järgi. Vajadusel tuleb ka karistada, et last õigele teele juhatada, sest lapse kasvades võib kasvatamiseks ja karistamiseks juba hilja olla. Küsimuseks jääb, mis vanuseni lapse nn painutamist on lubatav teha. Rahvatarkus siin detailidesse ei lasku.

b) Allkategooria: Kasvatus kui õppimine

Kasvatus ja õpetus käivad käsikäes. Seal, kus on õpetus, on ka kasvatus (vrd H. Liimets 1998). Kui vanasõnades räägitakse kasvatusest väga palju kujundite kaudu, mille tähendus võib kontekstis muutuda, siis õpetusest on juttu palju otsesemalt.

Kõige mahukama rühma moodustavad vanasõnad, mis edastavad sõnumit, et just nooruses on õige aeg õppida. See mõte lähtub samast ideest lapse õigeaegse kasvatamise kohta. 
Kuida sa noorelt kasvad, nenda sa vanalt jääd (EV 7479).

Kuidas nooruses küli, nõnda vanaduses vili (EV 7572).

Varsan õpid, vanan pead (EV 13858, 55 varianti).

Näidetest saab järeldada, et stereotüüpselt peetakse noorust parimaks omandamis- ja õppimisajaks. Paralleelselt rõhutavad vanasõnad ideed, et õppimine, areng ning kogemuste hankimine toimub kogu elu, ilma selleta ei saa.

Kui eläd, sis õpid (EV 555).

Inimene ei saa enne targas, kui kaits kanikud kokku kasvave (EV 2104).

Inimene õpib hällist kunni hauani (EV 2137).

Inime on kaheksakümmend aastat koolipoiss (EV 2142).

Õppimisel on eesmärk - see loob väärtust, uut kvaliteeti. Õppimise tulemust väljendatakse mitmel viisil: õppinud inimene on tark, rikas, teab ja mõistab rohkem. Vanasõnades väärtustatakse eriti tarkust. Sellele pööratakse tähelepanu mitmest aspektist.

Kes rohkem loeb, see rohkem teab (EV 6067).

See inimene on rikas, kes palju õppind (EV 9756).

Ei ükski sünni targaks (EV 11420, 25 varianti).

Kui tahad targaks saada, siis pead õppima (EV 11605).

Opi midäge, sis mõistat sina midäge (EV 14755).

Püüd tarkuse poole on inimesele loomuomane ja eeldab õppimist - keegi ei saa väita, et ta on valmis tark. Vanasõna ei ükski sünni targaks tähenduse kohta on arhiivis seletus: "Terve eluaa inimesed õpivad. Olgu tä mis asi tahes, ikka tuleb vaadata, õppi ja isi teha, siis saab targas ja võib teisi õpetada" (Hanila, I. Aavekukk, 1969). Oluline on, et õpetada saab siis, kui ise ollakse õppinud. Vanasõnad räägivad ka negatiivsetest teguritest, mis võivad õppimist takistada.

Ega lind pesan lendama ei õpi (EV 5876).

Ega tuul raamatut pähä ei too (EV 12216).

Kes õhkab õppides, see ei õpi elades (EV 14518).

Õppimist raskendavad tahtepuudus ja soovimatus pingutada. Vanasõnade järgi on kõige parem õpetaja elu ise. Vanemad annavad laste kasvatamisel oma panuse, kuid siis peaks noor iseseisvalt hakkama saama ja ise oma kogemused hankima.

Elukool on lai; kes selle läbi teeb, saab targaks (EV 594).

Ilmakool on kõige targemb (EV 2015).

Esa emaga ei ole ilm (EV 2181). 
Vanasõnad annavad selge sõnumi, et kui vanemate õpetussõnu pole kuulda võetud, siis elu jagab õppetunnid ikka kätte. Hoiatuseks ja ähvarduseks on mitmeid vanasõnu, kus elu hööveldab, peksab, lõikab saena jne. Sellised piltlikud väljendid peaksid hoiatama karmide ja kindlasti negatiivsete kogemuste eest, mida elu pakkuda võib.

Ilma vitsa pessäve valuste (EV 1960).

Ilm ei jäta kedagi hööveldämädä (EV 1961).

Küll ilm lutt, ilmasaag lõikab (EV 1998).

Küll ilm õpetab (EV 2000, 75 varianti).

Vanasõna küll ilm õpetab seletus näitab, et elu õpetab noort kogenematut inimest: "Kui elluastuja on isemeelne, kergemeelne, saamatu, laisk jne, või teda selleks peetakse" (Rakvere, V. Sardma, 1976). Moraal on, et kodust antakse kasvatusena kaasa õiged põhimõtted, õpetusi järgimata võib elus raskeks minna. Samas annavad vanasõnad ka lootust, et eluõppetundides võib ka inimene ise muutuda.

Vanasõnad hoiatavad halbade õppetundide eest elus. Kuid rahvatarkus edastab ka sõnumit, et elu ongi see jätkuva õppimise koht, kust teadmisi saada ja kogemusi hankida. Mõttetarkused rõhutavad, et õppimisprotsessis ollakse ise aktiivne tegutseja ja enda kasvataja.

\section{PÕHIKATEGOORIA: Kasvataja}

Kasvataja mõistet võib tõlgendada kitsamalt ja laiemalt. Kasvataja võib olla lapsele iga täiskasvanu, sh loomulikult õpetaja koolis, kuid ka kogukond ja ühiskond tervikuna.

a) Allkategooria: Vanemate rollid

Vanemad on peamised lapse kasvatajad, kuulekuse ja sõnakuulmise nõudjad, vajadusel ka karistajad. Lapsele on vaja kasvamiseks mõlemat vanemat. Tavaliselt vanemaid võrreldakse, ilmnevad soolised iseloomumustrid: ema on leebem ja hellem, isa on karmim ning valjem. Isa karistus on siis ka mõjusam.

Ema lööb kui lõngakeraga, aga isa lööb kui raudhaamrega (EV 613).

Esä hirm ja ema arm, mõlembit om latsele vaja (EV 2184).

Isa sõna enam kui ema vits (EV 2204, 17 varianti).

Pole nali, kui isa meel on vali (EV 7370).

Isa sõna maksab rohkem, vahel piisabki vaid sõnast, mille mõju võib olla kardetavam ja tähtsamgi kui ema vitsakimp. Isa autoriteetsust tõestab vanasõna isa sõna enam kui ema vits seletus: "Isa kasvatusvahendid on mõjukamad kui 
ema omad. Isa kardetse änam kui ema, ema oo ellem, ta vits põlena valus kui isa sõna" (Hanila, I. Aavekukk, 1969). Seega vanasõnad peegeldavad patriarhaalse ühiskonna võimusuhteid (vrd Vissel 2004) ja arusaamu. Räägitakse aga ema suurest, toetavast ja hädast väljaaitavast armastusest.

Ema armastus on keige suurem (EV 605).

Emä arm tõmbap merepõhjast vällä (EV 631).

Hä̈̈ poig tasu esä vaiva är, imä vaiva iälki (EV 1032).

Ku latsõl isä ärä koolõs, sis kaos täl puul armu ärä, a kui imä ärä koolõs, sis kaos tä̈̈s arm ärä (EV 5471).

Parem ema arm kui isa leib (EV 8402).

Vanasõnad näitavad, et ema osa laste kasvatamisel on peetud tähtsamaks ja tema kaotust laste jaoks korvamatuks. Võiks järeldada, et ehk sellepärast on ka emaga seotud vanasõnu rohkem. Emad kasutasid ka vanasõnu kasvatussituatsioonis enam kui isad. Soome vanasõnade põhjal on Liisa GranbomHerranen (2012) samuti järeldanud, et vanasõnu on kasutanud rohkem naised. Ka Oskar Loorits (1951: 30-35) on esile tõstnud soomeugrilaste kodukultuuri, kus perepeaks on arukas isa, aga südameks armastav ema, kes on iseseisvam ja laiemate ülesannetega kui naiste puhul tavaliseks peetakse.

Vanasõnade hulgas on eraldi teemarühm, kus vastandatakse oma ja võõrast, st peamiselt ema ja võõrasema. Kindlasti eelistatakse oma võõrale, vaatamata isegi probleemidele.

Paremb oma ema koorik kui võõraema võileib (EV 7994, 30 varianti). Parem on oma ema vits kui võõraema võileib (EV 8022, 110 varianti). Võõraemä tõrelamine om enamb ku oma emä pesmine (EV 14422).

Sellesse allkategooriasse kuuluvate tüüpide suur arv (andmestikus kokku 19 tüüpi) ja variantide rohkus võimaldab mitmeid ajastuomaseid tõlgendusi: ema ja kodu olid olulised; sageli oli emaks võõrasema (tulenes naiste suurest suremusest); lapsed pidid teenima võõraste juures; oma oli turvalisem, võõraga kaasnes ebakindlus ja oht. Vanasõna parem on oma ema vits kui võõraema võileib tõlgendajad hindavad tuttavat ja kodust, suunavad leppimisele: "Öeldakse selles mõttes, et oma ikka see kõige parem, olgu ta siis võileib või ka malk, aga olgu oma" (Jüri, E. Leek, 1982). Vanasõnad emast ja võõrasemast haakuvad muinasjuttude ja rahvalaulude vaeslapsetemaatikaga. Ka Arvo Krikmann (1997) on välja toonud vanasõnade seoseid regilauludega. Vanasõnad esitavad ka vanemate selget rollijaotust peres.

Isa on pere leiva tugi (EV 2199).

Kui isa ahju peal haigutab, külmetavad lapsed leelõukal (EV 2211).

Kõrge kiviaed on põllu hoidija, aga tubli naene on maja kaitsja (EV 3949). Ema pilli järele tantsib pere (EV 620). 
Vanemate rollid vastavad traditsioonilisele peremudelile (vrd Põld 1993; Kaimre \& Kraav 1998): ema on hoolitseja ja aitaja, temast sõltub pere kliima, isa on autoriteet ja pere toitja. Vanasõnades esinevad vanemad nii erinevaid arusaamu edastava vastandpaarina kui ka teineteist täiendavate partneritena. Isa on küll autoriteetsem, aga vanasõnades kajastatu järgi kuulub kasvatamises juhtpositsioon pigem emale.

b) Allkategooria: Vanemate austamine

Vanasõnad suunavad vanemaid ja üldse eakaid inimesi austama ja nende nõuandeid kuulama.

Halli pead austa, kulupead kummarda (EV 807, 100 varianti).

Kes vanemaid ei austa, see õnne ei leia (EV 13631).

Vanemate kord on au saada (EV 13514).

Täiskasvanute autoriteedi tagavad suurem elutarkus ja -kogemus: "Halli pead austa, kulupead kummarda. Vanu inimesi kässitse austada, nendest tuleb lugu pidada, elu oo neid õpetan" (Hanila, I. Aavekukk, 1971). Ema ja isa austamise nõue tuleneb juba piibli kümnest käsust, selle järgimisel lubatakse ka head elukäiku. Vanasõnad hoiatavad vanematele vastuhaku eest, millele järgneda võivad äärmuslikud tagajärjed viitavad austuse tähtsusele.

Kes isa ehk ema lööb, selle käsi kasvab hauast välja (EV 2207, 25 varianti). Kes laps vanemat lööb, selle käsi ei mädane hauas ära (EV 5456).

Kes oma vanemaid lööb, selle käsi ei käi ilmaski hästi (EV 7859).

Kuidas sina vanematele, nõnda so lapsed sinule (EV 13635).

Viimase näite põhjal võivad vanemate ja laste vahelised konfliktid kanduda ka järgmistele põlvkondadele. Ka tõlgenduse järgi olid need vanasõnad mõeldud just laste hirmutamiseks. Vanasõna kes isa ehk ema lööb, selle käsi kasvab hauast välja kasutuskontekst ütleb: "Selle jutuga hirmutati riiakaid lapsi, kes tahtsid pissest piast oma isa-ema lüia” (Hanila, I. Aavekukk, 1971).

c) Allkategooria: Vanemad kui eeskuju

Vanasõnades juureldakse küsimuse üle, kui palju saavad vanemad oma lapsi üldse kasvatada ja mis on lapsele juba sündides kaasa antud. Ütlustes vanemate mõjust oma laste käekäigule leidub mitmesuguseid ja ka lausa vastandlikke arusaamu. Väga suure tekstiarvuga vanasõnatüübid tõestavad, et lapsed käituvad ikka väga oma vanemate moodi.

Kuuse kannu pääle kõiv ei kunagi kasu (EV 4759, 25 varianti).

Käbi ei kuku kännust kaugele (EV 4910, 285 varianti).

Kuidas känd, nõnda võsu (EV 4934, 250 varianti).

Kuidas vana koer ees, nõnda kutsikad takka järele (EV 13342). 
Vanasõnad edastavad sõnumit, et sõltuvalt vanematest ei tasu lastelt oodata enamat või midagi teistsugust. Ka tänapäeval väga tuntud vanasõna $k \ddot{a} b i$ ei kuku kännust kaugele seletus näitab, et peamiselt mõeldakse sellega lapse ja vanemate iseloomude sarnasust: "Sii mõteltse ikka isiloomu. Kui vanemad oo ihntsad või laisad, siis õpetavad oma lapsed kua neukstes. Aga kui vanemad on elde südamega, siis lapsed kasuvad kua neukstes" (Hanila, I. Aavekukk, 1969). Arvo Krikmanni (2002) väitel ei ole selle vanasõna tähendus neutraalne, vaid viitab pigem halvale vanemale ning millegagi hakkama saanud järeltulijale. Kokkuvõttes võib vanasõnade järgi vanemate mõju lapsele olla nii positiivne kui ka negatiivne, oma osa on nii pärilikkusel kui ka kasvatusel.

Taas ilmneb ka sooline eristamine: stereotüüpse ettekujutuse järgi mõjutab ema rohkem tütart ja isa poega, ning lapsed jälgivadki rohkem samasoolist vanemat.

Kuidas ema, nõnda tütar (EV 649, 40 varianti).

Kudas isa ees, nõnda poeg taga (EV 2208, 30 varianti).

Pojad on isa rees (EV 8930).

Varss opis vanast märäst, tütär imäst (EV 13861).

Arhiivikirjelduse järgi kaldub vanasõnade tähendus vanemate positiivselt eeskujult pigem halvale mõjule: "'Kudas esä ehen, ninda poja perän," üteldse, ku vanempe lastele halba esimärkki annave" (Halliste, H. Schulzenberg, 1897). Viimase näite varss opis vanast märäst, tütär imäst tähendust on seletatud: "Kui tüdar eksub samate nenda kui emä eel" (Kuusalu, S. Hirrend, 1939). Kui laps käitub halvasti, vaadatakse esmajärjekorras vanemate poole. Vanasõnad annavad aga ka vastupidise võimaluse: vanemate järgi ei saa lapse üle otsustada, tema elu ja käitumine võib kujuneda hoopis teistsuguseks.

Olgu isa sikk või ema kits, kui aga ise mees olen (EV 2217, 30 varianti). Must kana munõ valgõ muna (EV 6945).

Virgad vanemad, laisad lapsed, laisad vanemad, virgad lapsed (EV 14225).

Vanasõnades on alati olemas võimalus, et laps võib olla oma vanematest erinev, nii positiivses kui ka negatiivses mõttes. Vanasõna olgu isa sikk või ema kits, kui aga ise mees olen edastab, et järeltulija saab olla oma vanematest parem ja edukam: "Selle pääle ei pea vaatama, mis vanemad olnud, kui keegi aga isi tubli mees on" (Halliste, J. Jung, dateerimata).

Vanemad peaksid olema eeskujuks, soovides lapsele parimat. Vanemad vastutavad uue põlvkonna kasvatuse eest. Küsimus aga jääb, kui palju saab last ikkagi mõjutada. 
Ema pistab rinna suhu, aga ei pista meelt päha (EV 621, 95 varianti).

Ei laidete last, vaid latse kasvatajat (EV 5412).

Orasest ei tunta veel vilja (EV 8075).

Vanasõnaga ema pistab rinna suhu, aga ei pista meelt päha saavad vanemad end õigustada olukorras, kus laps ootuspäraselt ei käitu: "Lapse kohta, kes vanematele mielehärmi, tuska tieb, jusku vabandatakse vanemaid, kui laps on üleannetu" (Lüganuse, A. Källo, 1965). Vanemate järgi ei saa otsustada laste elu üle. Eeskujuks olemist kui üht kasvatusmeetodit peavad oluliseks ka kasvatusteadlased (nt Põld 1993). Et vanemate roll laste kasvatamisel on väga oluline, seda tõestab ka eeskuju allkategooriasse kuuluvate vanasõnade suur arv (valimis kokku 79 tüüpi).

\section{PÕHIKATEGOORIA: Kasvatatav ja kasvaja}

Vanasõnad edastavad hoiakuid, kuidas on lapsesse aegade jooksul suhtutud. Lapse kujutamisel tulevad esile tema positsioon peres, hinnangud hea ja paha lapse kohta ning laste soolised erisused.

a) Allkategooria: Lapse positsioon perekonnas

Laste olemasolu peres peeti tähtsaks eelkõige pragmaatilisel põhjusel, sest lastes nähti abi talutööde juures (Vissel 2004). Lapse saamist ja emaks olemist peetakse vanasõnades naise elu loomulikuks osaks.

Lat's um tarõ ilo, põrss um muro ilo (EV 5562).

Mees nägusam, kui piip suus; naine nägusam, kui laps süles (EV 6587, 20 varianti).

Oige inimene tuob lapse ilmale (EV 14551).

Laps on vanasõnades sageli allutatud seisundis, ta peab käske täitma, tema mõtteid ja tundeid peetakse ebaolulisteks. Laps peab kõigega leppima, pahatihti karistamisel põhjust nagu polekski.

Kesse lapse pilli järele tantsib (EV 5457).

Laps nutab, kui pestakse, pärast magab magusamast (EV 5524).

Parem nutku laps ku vanem (EV 7606).

Oma lapsega võib keik teha - lüe ehk lükka (EV 7921).

Lapse madalamat positsiooni näitavad ka mõtted, et lapsed erilist hoolt ja tähelepanu ei vajagi.

Kessi kitsi peräst kuhja luu vai latse peräst soola tuu (EV 3895).

Lapse häda ja koera häda oleva üks ja seesama (EV 5491).

Lapse nahk ja koera nahk (EV 5505). 
Viimastes näidetes võrreldakse last kujundlikult koeraga, pigem siis kutsikaga, kes on veel noor ja rumal. Lapse eest hoolitsemiseks on piltlikult niisama vähe vaja kui koera jaoks. Vanemate ja lapse suhe ei põhine vanasõnades võrdsetel alustel. Lapsel pole sõnaõigust, teda ei kuulata, tema arvamusega ei arvestata. Vanasõnad annavad selge sõnumi, et laps olgu lihtsalt vait.

Las vana koer haugub üksi, mis kutsik sekka haugub (EV 4150).

Laps räägib siis, kui kana kuseb (EV 5531, 40 varianti).

Vanasõnu on kasutatud keelamiseks: lapsed ärgu sekkugu täiskasvanute jutusse, kuulaku vanemaid ja ärgu vastu hakaku. Vanasõna laps räägib siis, kui kana kuseb on pruugitud näiteks olukorras: "Kui vanemad inimesed räägivad ja lapsed tahavad vahele rääkida, siis keelab isa ehk ema neid järgmiste sõnadega" (Haljala, J. A. Reepärg, 1938). Kasvatusteadlase Maria Tilga (2000) arvates väljendab vanasõna laps räägib siis, kui kana kuseb selles kontekstis hoopis sallimatust tühja jutu ajamise vastu. Nii saab laste vaikima sundimisele läheneda ka hoopis teise nurga alt.

Omaette rühma moodustavad nn muna ja kana vahekorda väljendavad vanasõnad. Selguse mõttes esitame kõik võimalikud variandid.

Kana on targem kui muna (EV 3132).

Koor on ikka targem kui muna (EV 4345).

Ega muna kana ei õpeta (EV 6891).

Muna on targem kui kana (EV 6901, 105 varianti).

Muna pole targem kui kana (EV 6902).

Muna õpetab kana (EV 6903, 20 varianti).

Vanasõnu võib mõista kui laste ja vanemate vastastikust kasvatamist ning õpetamist. Kontekstikirjelduste järgi selgubki vanasõna muna on targem kui kana ambivalentsus: "Muna tahab targem olla kui kana, laps tahab vanemast targem olla” (Iisaku, E. Maasik, 1987); "Üteldakse, kui mõni laps mõnda enam mõistab, kui ema või teine vana inimene" (Saarde, J. Sõggel, 1937). Kuigi vanasõna järgi saab vaadata lapsi kui eelkäijatest targemaid järeltulijaid, on kasutuse järgi rõhk olnud ikkagi iroonilisel tõlgendusel (Järv 2019). Lapse tahtesse olla targem, iseseisvam ja oma arvamusega suhtutakse pigem pilkavalt ning seda peetakse n-ö ninatarkuseks. Õpetajateks jäävad ikkagi lapsevanemad, lapse ja vanema võrdset suhet siin ilmsiks ei tule.

Samas tunnistavad vanasõnad, et lapse jutus võib tõetera sees olla. Stereotüüpselt peetakse lapsi ausamateks ja siiramateks.

Ega lapse suu ei valeta (EV 5443).

Latse and om armas, latse sõna om valus (EV 5544). 
Kokkuvõtteks: laste olemasolu peres on peetud tähtsaks, kuid vanasõnakorpuse järgi otsustades on nad madalamal positsioonil. Teisiti öeldes: rahvatarkust on kasutatud olukordades, kus on tarvis nende madalamat positsiooni esile tuua. Lapsed on veel "rohelised" ja kogenematud, neid peab juhatama ja juhtima õigele rajale. Lapse mõtted ja tunded pole need, mida peaks kuulama ja millega peaks arvestama.

b) Allkategooria: Hea ja halb laps

Vanasõnadest ilmneb selge vastandus: hea laps ja paha laps. Heal lapsel on palju eeliseid: teda pannakse tähele, ta tekitab vähem muret, tema soove täidetakse, ta ei pea kartma vitsasaamist.

Hea laps mõistab sõrme näitust, paha lapsele ei aita peksminegi (EV 932). Hea laps on vanama abi (EV 934).

Hiad last nähasse igal pool, paha ei pane keegi tähele (EV 985).

Paha laps ei saa paludeski, hea saab ilma küsimata (EV 8224).

Vähe on selgitatud, mida heas lapses täpsemalt esile tõstetakse. Näidetest on näha, et hea laps on sõnakuulelik ja abivalmis. Hea laps saab ise hakkama, ei valmista vanematele muret ega tekita tüli ja toob vanematele kuulsust. Halva lapsega on vanematel rohkem muret. Paha laps on näiteks sõnakuulmatu ja kuri.

Hää laits võtt poole tööd, kuri laits puha töö ära (EV 1008).

Kuri laps on vanema vits (EV 4620).

Sõnakuulmata laps on vanematele kirstunaelaks (EV 11146).

Probleemse lapsega on rohkem vaeva, mida tõestab ka vanasõna sõnakuulmata laps on vanematele kirstunaelaks seletus: "Nad on oma vanematele ristiks kaelas" (Viljandi, J. Kala, 1949). Küsimusele, millest on lapse ebasoovitav käitumine tingitud ja mis roll on selles vanemate kasvatusel, vanasõnad ei vasta. Paremaks peetakse last, kellega ei ole probleeme. Iga vanema jaoks võivad olla lapse headuse hindamisel aga erinevad kriteeriumid.

c) Allkategooria: Soolised erisused

Poisse eelistatakse tüdrukutele. Arvestades varanduse pärimist ja panust majapidamisse talurahvakultuuris, on see ka mõistetav.

Poig õks om esä abi, a tütär om esä üsätse varas (EV 8927).

Poig õks paremb ku tütär, olkõ’ vai kolmõst paigast niitsega kinni kö̈̈ted (EV 8928).

Tütarlapsed laotavad maja, aga pojad koguvad (EV 12776).

Üleannetu poiss ja pahur siga-need teevad alati pahandust (EV 15105). 
Vanasõnadest selgub vanemate arusaam, et lastest peaks ka kasu olema. Poja panust hinnatakse rohkem, isegi kui tal on mingi puudus. Tütrest kasu ei nähta, lahkudes viib varagi vähemaks (tuli ju toonaste tavade kohaselt anda abielluvale tütrele kaasavara, teha kingitusi peigmehe suguvõsale). Poja kasvatamisel võib ka olla probleeme, kui ta on näiteks sõnakuulmatu. Valitseb aga arusaam, et tüdrukute kasvatamine peaks olema rangem.

Tütär hoia vitsahirmul nagu märävarsa (EV 12771).

Tütärt tündsi tüvega, poiga lasõ ladvaga (EV 12773).

Vanasõnad annavad tüdrukute kohta ka märksa enam iseloomustust ja juhtnööre. Väljanägemisest enam hinnatakse tütarlaste töökust, tegutsemist eelistatakse rääkimisele.

Muи puи muhaku, lepa leht lehaku, tütarlats olke vai (EV 9096).

Tüdrukud ei küsi, olgu ta sunt ehk sant (EV 12602).

Tütar ike tü̈̈inime, et ep õle iluperäne (EV 12751).

Tütarlaps tööta on nagu teekäija ilma vööta (EV 12785).

"Emal oli selline ütlus: "Muu puu muheleva, siis lepapuu leheleb." Meid oli neli tütart ja meid kasvatades ütles ta ikka, et tütarlaps peab olema nagu lepapuu, nii tasane ja kombeline" (Otepää, A. Väljaots, 1982). Vanasõna muu puu muhaku, lepa leht lehaku, tütarlats olke vai konteksti põhjal võib järeldada, et emad oma tütreid vanasõnade suuniste järgi ja abil kasvatasidki. Töökal tütarlapsel oli hea võimalus mehele saada. Veel 20. sajandi alguses oli abiellumine igati normikohane käitumine. Meheleminemise ja naisevõtmise teema on ka vanasõnades laialt ja mitmekesiselt kajastatud. Omaette aspekt on üldine suhtumine naissoosse. Väljendatakse mõtet, et õige tüdruk on pigem vait kui räägib, küsib või avaldab arvamust. Seega peetakse tüdrukuid/naisi justkui rumalamateks, keda ei maksa kuulata, sest nad ei tea midagi ega saa aru. Samas võivad need tüdrukute kasvatamise vanasõnad püüda ennetada stereotüüpset ettekujutust naistest kui lobisevatest, uudishimulikest ja sõnakatest olenditest. Ka eesti fraseologismides on Anneli Baran (2010b: 97-98) täheldanud, et ülemäärane jutukus on iseloomustanud just naisterahvaid. Seetõttu ilmselt hinnataksegi tüdrukute juures tagasihoidlikkust ja leplikkust.

Kokkuvõtteks võib öelda, et püüd tüdrukuid kindlamatesse raamidesse suruda on arvatavasti tinginud ka vastavaid nõudmisi dikteerivate vanasõnade suurema hulga. Samad tendentsid seoses soolise aspektiga on ilmnenud ka fraseoloogia uurimisel (vrd Baran 2010b: 102). 
d) Allkategooria: Kasvav inimene

Siia gruppi on koondatud vanasõnad, mis väljendavad inimeseks olemise ja kasvamisega seotut üldisemalt. Rahvatarkus nendib stereotüüpset tõde, et kõik inimesed on erinevad.

Igaühel on oma head ja vead (EV 1079, 25 varianti).

Pole kõik inimesed ühe vitsaga löödud (EV 2175).

Igal linnul oma laul (EV 5896, 120 varianti).

Iga inimest tuleks võtta sellisena, nagu ta on. Vanasõnad nendivad mustvalgelt, et on nii halbu kui ka häid inimesi. Vanasõnale igal linnul oma laul võib huvitaval kombel paralleeli leida Martin Heideggeri filosoofiast (vrd Liimets \& Koit 2018: 36-41), kus inimest on võrreldud lauluga, mis peaks väljendama igaühe eripärast teed keelelis-rütmilise maailma kaudu iseendaks saamiseni.

Vanasõnad edastavad arusaamist, et inimese põhiloomust muuta ei saa. Kuna ollakse võimetelt erinevad, siis pole ka saavutused võrdsel tasemel.

Ei pea ennast laiemale laotama, kui inimene on (EV 5291).

Ei või ükski oma münti ümber värvida (EV 7109).

Kõik tiivad äi kanna ühekõrgusele (EV 12003).

Kuigi vanasõnad räägivad ka eluaegsest õppimisest ja kasvamisest, väidab argitarkus siiski, et areng saab toimuda vaid teatud piirides ning inimene jääb oma olemuselt ikka samaks. Paljutki olevat inimeses ette määratud. Selle idee laia levikut tõestab ka vanasõnatüüpide suur arv. Tõdetakse ka, et see, kes juba noorelt on halb ja kuri, on seda ka vanemas eas. Selgitusi ei leidu, miks ja kuidas inimesed halvaks muutuvad.

Koerale jääväd ike koera hambad (EV 4061).

Kellest konks peab saama, sii on noorelt kõver (EV 4301).

Kellest okas peab saama, see on varakult terav (EV 7792).

Kogu arenguprotsessis olevat olulisim, et inimene õpiks eelkõige ennast tundma. See on ideaal, mille poole elus pürgida.

Igamees on ise oma kõige lähem ligimene (EV 1912).

Igaüks on oma olemise tegija (EV 1925).

Õpi iseennast tundma (EV 14760).

\section{PÕHIKATEGOORIA: Kasvatusmeetodid}

Kasvatuse eesmärkide saavutamiseks on erinevaid kasvatusmeetodeid: eeskuju, käsud, keelud, karistamine ja kiitmine (vrd Põld 1993). 
a) Allkategooria: Kehaline karistamine

Karistamise all mõeldakse kas füüsilist või verbaalset toimimist. Ülekaalus on arusaam, et lapse kehaline karistamine on vajalik, või hea on ka, kui arm ja hirm on koos. Vähe on vanasõnu, mis füüsilist karistamist ei poolda, pigem on see tavaline kui erakordne tegevus. Lapsele vitsa andmine ja üldse kehaline karistamine käib igapäevase elu juurde.

Ega siis hing hukka ei lähe, kui ihu harida saab (EV 1277, 25 varianti).

Liha ei kõlba soolata ja lats ilma vitsata (EV 5806).

Vili ei kasva vihmata ja lats ilma vitsata (EV 14191).

Vitsaga peksmine last ei tapa (EV 14258).

Vanasõnalisest argitarkusest saab järeldada, et karistamisel tõsiseid tagajärgi pole olnud, midagi halba see ei tee, pigem toob kasu. Antud tegevuse õigustuseks saab kasutada vanasõna ega siis hing hukka ei lähe, kui ihu harida $s a a b$ : "Peksul on kasvatuslik tähtsus. Üteldi laste karistamisel kui ka siis, kui mees mõnikord peksis naist" (Jõhvi, E. Mets, 1961). Vanemate positsioonilt kehalist karistamist millekski eriliseks ei peeta, pigem pisendatakse olukord vähetähtsaks.

Vanasõnad annavad karistajale aga nõu, et vihaga ei tohiks vitsa kasutada ja pärast karistamist ei peaks kahetsema.

Vihaga peksad - viha külvad, heaga peksad - head külvad (EV 14019).

Kui last karistad, siis ära kahetse perra (EV 5465).

Ka kasvatusteadlane Peeter Põld (1993) on väljendanud sama mõtet, et karistus peaks olema läbimõeldud, et laps saaks aru, mille eest teda on karistatud. Kogu vanasõnade andmestik annab aga vähe infot lapse käitumise või omaduste kohta, mis on nõudnud karistamist. Põhjus võib olla, et laps on sõnakuulmatu, jonnakas, üleannetu, ei kuula keelamist ega sõnalist noomimist.

Kes koerust teeb, see kolki saab (EV 4197, 70 varianti).

Paha lastele ja ülekohtustelle on Jumal kaseoksad loonud (EV 8225).

Kes head ei kuule, peab kurja kuulma (EV 1084).

Kes vanemate sõna ei taha kuulda, peab vasikanahka kuulma (EV 13632).

Vanasõna kes koerust teeb, see kolki saab tähendust on selgitatud: "Koer saab kolki, aga seda said varemalt lapsedki, kes ei kuulanud sõna, tegid üleannetust, s.t koerust" (Pärnu, S. Karu, 1966). Kontekstikirjeldus annab ühese seletuse, et üleastumisele järgnes kohe karistus. Samas peab arvestama, et need vanasõnad võisid olla pigem laste hirmutamiseks ja korrale kutsumiseks kui vanemate tegevuse õigustamiseks. Karistamisega loodetakse ka negatiivse 
kaudu jõuda positiivse tulemuseni. Et see muudab lapse paremaks ja võib teda päästa kõige halvemast. Karistamine väljendab sel juhul armastust, hoolimist ja vastutustunnet seoses oma järeltulijaga.

Tarkus läheb tagapoolt sisse (EV 11676).

Vits kasutas hää latse (EV 14261).

Vits om viha rohi (EV 14262).

Vitsahoobi kisuva latse hinge põrgust vällä (EV 14267).

Mida armsam laps, seda kibedam vits (EV 367, 175 varianti).

Kes hirmuta kasvab, see auta elab (EV 1296, 30 varianti).

Kui latse pessä-äi', sis latsõh pesvä eis (EV 5470).

Kes oma last armastab, see teda ka karistab (EV 7856).

Vanasõna kes hirmuta kasvab, see auta elab saab tõlgendada mitmeti. "Kui sõnakuulmatule lapsele vitsa anti, siis öeldi: "Kis hirmuta kasvab, sii auta elab"" (EV 1296, Tori, L. Rohtla, 1985); "Kes oma last mitte karistuse all ei kasvata, see saab temast eluajal häbi" (EV 1296, Halliste, J. Jung, dateerimata). Vana-sõnaga saavad vanemad põhjendada nii oma tegevust kui ka viidata halva kasvatuse tagajärgedele.

Vanasõnas kes oma last armastab, see teda ka karistab üksteist justkui välistavaid tegevusi põhjendatakse järgmiselt: "On päris õigesti öeldud, kui selle üle natuke järele mõelda. Liigne hellitus, lasta lapsi teha kõik, mis neile meeldib, on mõnedki lapsed, noorukid ära rikkunud. Vanasõna näitab, et vanemad peavad lapsi õpetama piiri pidama oma tegevuses ja väljendusis" (Pärnu, S. Karu, 1970). Siin on karistusel arvatavasti laiem tähendus, mis ei piirdu üksnes füüsilise karistusega. Vanasõna kontekstikirjeldus näitab, et karistus on vahend laste keelamiseks, korrale kutsumiseks ja piiride seadmiseks. Karistamata jätmine tähendaks halba kasvatust, laps oleks siis hellitatud ja kohe ka rikutud.

Analüüsi tulemusena saab väita, et laste kehaline karistamine oli tavapärane kasvatusviis. Kui räägitakse kasvatamisest, siis mõeldaksegi tihti kohe karistamist. Ka Matthias Johann Eiseni “Eesti vanasõnade” (1993: 43-44) väljaandes on üheks pealkirjaks "Kasvatus, karistus". Ene Vainik (2016: 162) toob välja, et arusaam laste karistamise vajalikkusest "on olnud meie esivanemate kaljukindel pedagoogiline printsiip". Traditsioonilisele ühiskonnale omane "õiglase vanema" ja "üleannetu lapse" suhet saab üle kanda ka teistele sotsiaalsetele jm suhetele. Nii on allumine ja hirmutunne "kinnistunud juba meie geneetilisse koodi ja käitumismustritesse, rääkimata siis keelest ja kultuurist”. 
b) Allkategooria: Kehalise karistuse eitamine

Arhiivmaterjalides on olemas vanasõnad, mis ei soovita last füüsiliselt karistada või on üldse selle vastu, kuid selliste vanasõnatüüpide ja tekstinäidete hulk on tunduvalt väiksem kui karistusteemaliste näidete hulk. Vanasõnades siiski usutakse et sõnal on mõnikord suurem mõju kui füüsilisel sekkumisel. Verbaalselt saab noomida, ähvardada, solvata ja nii võib rohkemgi haiget teha kui füüsiliselt.

Lahke sõna aitab rohkemb kui vits (EV 5286).

Parem suutäis hääga ku keretäis pahaga (EV 10960).

Sõna on valusamb kui vits (EV 11129).

Sõnahoobid on vahest valusamad kui käehoobid (EV 11144).

Vanasõnad edastavad, et hea lapse korralekutsumiseks piisab märkusest või noomitusest. Kui heaga ei saa, siis pole ka füüsilisest karistamisest kasu, inimene paremaks sellest ei muutu, pigem võib isegi olukord halvemaks minna.

Aru ei saa persest pähä panna (EV 397).

Hea laps mõistab sõrme näitust, paha lapsele ei aita peksminegi (EV 932).

Peks ei paranda inimest (EV 8524).

Vilets vitsul peksetakse, õnnis suul õpetakse (EV 14178, 60 varianti).

Vanasõnakontekst tõestab sõna mõju eeliseid: "Vanaema kaitses meid, ütles alati emale: "Kuule, tütar, ütlen sulle - vilets vitsal peksetakse, õnnis suule õpetakse““" (Anna, E. Kõiva, 1965). Osad vanasõnad edastavad sõnumit, et oma laps on ikka kõige armsam, ja kui on ainus, siis teda säästetakse karistusest. Head last polegi vaja karistada.

Hea laps kasvab vitsata (EV 928).

Kes ainust last raatsib lüüa (EV 5455).

Oma laits om iki kõege armsamb (EV 7919).

Tihti väljendavad vanasõnad vastandlikke arusaamu, mis annavad õigustuse mitmesugustele käitumisviisidele. Sealjuures annavad lisainformatsiooni vanasõna variantide suur maht ja lai levik. Selle põhjal on kasvatusmeetodina kehalisel karistamisel selge ülekaal.

c) Allkategooria: Hirm ja arm kasvatuses

Selle kategooria alla kuuluvad vanasõnad, mis sisaldavad otsest vastandust: hirm ja arm ehk rahvakeeles ka piits ja präänik. Kasvatamisel leitakse olevat vajalikud mõlemad. Peaks olema nii armastust, headust kui ka karmust ja karistamist. Üks võib tingida teise. 
Arm ja hirm on mõlemad õigel ajal hä̈̈d (EV 351).

Hirm armuga omma velitse (EV 1287).

Kus ei ole hirmu, sääl ei ole armu (EV1298).

Lapsele anna hirmu ja armu (EV 5438).

Viimase vanasõna juurde antud selgitust saab laiendada kõigile näidetele: "Laste kasvatamisel peab neile armastust ja karistust jagama" (Emmaste, J. Kõmmus, 1968). Hirmu ja armu mõju ei hinnata alati võrdselt, see sõltub olukorrast, millist viisi kasulikumaks peetakse. Vanasõnades esitatakse ka teistsuguseid vastandusi kasvatusviiside väljendamiseks.

Laits saab laadelt saia ja peran laadet pessa (EV 5478).

Noore hobusele ja lapsele anna süüa ja peksta (EV 7491).

Vits hüäh käeh, kulatsk kurah käeh kasvada last (EV 14260).

Rahvatarkuses peitub ka võimalus, et vahel on üks kasvatusviis parem kui teine. Selge eelistuse saab siis positiivne mõjutamine. Negatiivseid meetodeid kasutatakse vaid äärmuslikel juhtudel.

Arm aitab enam kui hirm (EV 349, 30 varianti).

Ennem armuga, pärast hirmuga (EV 358).

Enam saab heaga kui kurjaga (EV 893).

Hirm aitab enam kui arm (EV 1286).

Veendumust sõna ja armastuse jõusse väljendab ka vanasõna arm aitab enam kui hirm tõlgendus: "Ja sõna ja armastusega saab paremini last kasvatada kui hirmutamisega. Vanadel oo samma lugu kua" (Hanila, I. Aavekukk, 1971). Samas ei puudu vanasõnades vastupidine mõte (vrd Järv 2019), et karistamisest on rohkem kasu kui heast sõnast. Mõned vanasõnad väljendavad laste erinevat kohtlemist, s.t kõigile ei jagata karistust ühtemoodi.

Anna üheksale hirmu, kümmes kuuleb armu (EV 14828).

Üte omma hirmulatse, / tõõsõ armulatse, kolmanda kur'a ole-ei kinkki latse (EV 15054).

Öeldu haakub kasvatusteadlase Peeter Põllu (1993) nn hirmutusteooriaga, et ühe lapse karistamine distsiplineerib teisi lapsi. Keeleteadlane Ene Vainik (2016: 157-158) on toonud välja sõna hirm vananenud tähenduse - s.t karistus, ihunuhtlus, peks, millest tuleneb ka väljend vitsahirmu andma. Seega kui sõna hirm võiks assotsieeruda ka ähvardamise, sundimise ja samuti märkuse, noomitusega, siis tegelik tähendus väljendab ikkagi füüsilist karistamist. Vainik nendib, et regilauludes seostub hirm karistuse tähenduses just koduga. 
Vastandsõna arm on tõlgendatav halastusena. Vainiku (ibid.: 174-176) väitel vanarahvas ei tundnudki sõna armastus. Regilauludes esinevad vormid arm ja armud, kus armud esineb vastastikuse kiindumus- ja armastustunde tähenduses ja arm väljendab hierarhilist suhet, st "ülalt alla" osutatavat kaitset, soosingut ning halastust.

d) Allkategooria: Kiitus ja laitus

Enamik kiitmist ja laitmist väljendavatest vanasõnadest ei ole otseselt sihitud lastele, vaid kasutatavad kõigi inimeste kohta. Kasvatusteadlased (vrd Põld 1993; Tuulik 2001) on seisukohal, et lapsi peaks kiitma mõõdukalt ja läbimõeldult. Laste puhul räägitakse positiivse tunnustamise asemel pigem hellitamisest. Vanasõnad laste hellitamist ei poolda, tuues sellega seoses mitmeid põhjendusi.

Hellitad last, siis kasvatad karu (EV 1215).

Ära hellita poega, pärast nutad tema käes (EV 1218).

Hull kiidab orja tööd, laisk kiidab lapse tööd (EV 1564, 30 varianti).

Laps ja loll tahavad kiita ja kass tahab silitada (EV 5514).

Ei palja paiga kasvata sa poisslapsi üht (EV 8250).

Eeltoodud näidetest nähtub, et hellitatud laps võib hoopis hukka minna. Ekstra hoiatatakse poiste nn nunnutamise eest. Lapse kiitmist isegi naeruvääristatakse, s.t lapse soovi kiita saada ei tohiks tõsiselt võtta või üle tähtsustada. Kahtluse alla seatakse, kas laps suudabki midagi kiitmisväärset teha või korda saata. Vanasõnadest võib välja lugeda soovituse, et kiidetavat inimest peaks hästi tundma: kui ta on end heast küljest näidanud, pingutanud ning vaeva näinud, siis on ta ka kiituse välja teeninud.

Ei tohi kedagi enne kiita, kui külimit soola üheskoos on ära söödud (EV 3719).

Laisal palju laitjaid, virgal palju kiitjaid (EV 5333).

Linda kitetas laulust, inimest kombist (EV 5934).

Ikki töö ja teu järgi tuleb kiita, mitte pilli ja piu järgi (EV 12441).

Kasin kiitmine võib tuleneda ka ebausust, et enneaegne rõõm võib peagi asenduda ebaõnnega, parem olla kõiges pigem mõõdukas ja alalhoidlik. Kui hästi tehtud töö toob tunnustust ja näitab positiivselt ka selle töö tegijat, siis eraldi kiitmine oleks juba ülearune.

Hea asi kiidab iseennast (EV 410).

Töö kiidab tegijat (EV 12515, 100 varianti). 
Vanasõna töö kiidab tegijat variantide hulgas tunnustatakse ka meistrit: "Tüü kitt meistret. Töö järele tuntakse ära hää ja tubli töömees" (Otepää, A. Kroon, 1938). Viimane vanasõna pärineb piiblist, kuid on ka tänapäeval väga tuntud. Kiitmise ülesanne on motiveerida ja julgustada.

Ettevaatlikkusele manitsetakse inimeste puhul, kes võivad teisi kiita omakasu silmas pidades.

Mida enam kassi silitad, seda kõrgemale ta saba tõstab (EV 3400, 60 varianti).

Mida rohkemb kassi söödetas, seda hooletumb elu om rottel (EV 3401).

Kiida lolli, loll jookseb nahast välja (EV 3730).

Vanasõnad kinnitavad tõdemust, et ühelt poolt paneb kiitus inimest endast rohkem andma ja end ületamagi, teisalt antakse mõista, et tuleks ikka ettevaatlik olla, sest keegi võib lihtsameelset oma huvides ära kasutada.

Kiitusele vastandatakse laitust. Mõnedes vanasõnades esinevad need mõisted koos. Ka sellises klassikalises vastanduses on mitmed tähendusnüansid võimalikud. See on igaühe subjektiivne otsus, mida kiita või laita.

Keegi pole nõnda hea, kui kiidetakse, ega ükski nõnda paha, kui laidetakse (EV 1149).

Paremp kitta ku laita (EV 3739).

Parem targa laitus kui lolli kiitus (EV 11611).

Mida üks kiidab, seda teine laidab (EV 14893).

Üht kiidetakse sita sisse, teist laidetakse ausa töö juures (EV 14948).

Arvo Krikmann (1997: 278-279) väidab, et "just hüperboolsed hinnangud osutuvad tihti vääradeks”. Üldkokkuvõttes võib analüüsi tulemusel öelda, et kiitmisega ei soovitata liialdada, enne tunnustamist tuleks oma otsust kaaluda. Üldise tendentsi kohaselt vanasõnades kiitmist ei pooldata. Väidetavalt ka tänapäeval kiidetakse nii kodus kui koolis lapsi liiga vähe (vrd Pärismaa 2018). Kõige efektiivsemaks kasvatusmeetodiks on peetud karistamist, sh kehalist karistamist. Seega on vanasõnades esindatud pigem negatiivsed kasvatusviisid, nagu ka varasemates vanasõnauurimustes (nt Stanciu 1986) on täheldatud.

\section{Vanasõnade argitarkuse haakumised eesti kasvatusteadusliku mõttega}

Artikli mahu piiratuse tõttu pole siin võimalik hakata vaatlema kõiki eesti kasvatusteaduses ringvel olnud käsitusi kasvatusest. Osutame üksnes vanasõnade sisust koorunud kasvatuse tähenduste haakumistele vastava eesti kasvatusteadusliku mõttega. 
Airi Liimets (2009: 386-389) on analüüside tulemusena nimetanud viimase ca 70 aasta jooksul eesti kasvatusteaduses enamlevinud kasvatuse teaduslike määratlustena järgmisi: 1) kasvatus kui interaktsioon; 2) kasvatus kui arengu juhtimine; 3) kasvatus kui elutegevuse organiseerimine ehk elustiili kujundamine; 4) kasvatus kui arenguks tingimuste loomine; 5) kasvatus kui identiteedi loomine: 6) kasvatus kui inimese struktuur; 7) kasvatus kui väärtustamine. Neist kaks esimest käsitust on tekkinud biheivioristlikus mõtlemiskontekstis ning olid eesti kasvatusteaduses eriti arvestatavad 1950. aastatest kuni 1980. aastate keskpaigani, kuid kasvatuspraktikas ja koolitegelikkuses on need tajutavad tänapäevani, on kõige levinumad, piiritlevad mõtlemist, arusaamu ning suunavad käitumist. Seitsmes käsitus on n-ö aegadeülene, nimetatutest ülejäänud ehk kognitivistlikku mõtlemisviisi esindavad määratlused hakkasid eesti kasvatusteaduses eriti levima alates 1980. aastate keskpaigast. Nagu vanasõnade analüüsist järeldada võib, haakub neis peituv argitarkus kõige enam biheivioristlike käsitustega kasvatusest kui interaktsioonist ja arengu juhtimisest.

Nagu ilmnes vanasõnadest, peab ka teaduslik määratlus kasvatus kui interaktsioon silmas, et kasvatus on protsess, milles on kaks osapoolt: kasvataja ja kasvatatav. Kasvatus on seega määratletav kasvatussuhte kaudu (nt Liimets 2009; Kuurme 2003: 10; Kraav 2003: 27). Heino Liimetsa (1974) järgi muutub interaktsioon tõeliselt vastastikuseks alles kasvatajapoolse mõjutuse vastuvõtmise kõrgeimal - sisemise omaksvõtmise ehk interiorisatsiooni - tasandil. Sellest madalamatel tasanditel - s.t mõjutusega nõustumise või sellega väliselt samastumise korral - on tegemist kasvataja võimupositsioonilt toimuva mõjutamisega, kus kasvatatav on passiivne, allutatav ja käskudele kuuletuv. Antud sisu iseloomustab biheivioristlikku mõtlemist kasvatusest, mida võisime täheldada ka vanasõnades. Ent Johannes Käis (2018: 23) on juba 20. sajandi algul väitnud, et kasvatusprotsessis peaks kasvataja suutma välise mõjutamise kaudu kutsuda esile sisemist arengut.

Biheivioristlike tõekspidamistega haakub ka vanasõnadest ilmnenud vajadus arvestada kasvatamisel lapse eripära, mis peamiselt tähendas kasvatuse õigeaegsust - s.t et üksnes lapseeas ja nooruses saab inimest millekski sundida ja kasutada selleks jõudu. Osutati ka negatiivsetele tagajärgedele, kui seda ei tee, ning väideti, et elu annab siis nagunii oma õppetunnid. Kasvatamist ja õppimist/õpetamist vaadeldakse nii vanasõnades kui ka biheivioristlikus kasvatusteaduses peaaegu sünonüümidena, käsitades mõlemat kui arengu juhtimist inimesest väljastpoolt. Ka eesti kasvatusteaduses on nt Heino Liimets (1985, 1998) palju kirjutanud kasvatavast õpetamisest, mis tema meelest seostub aga eelkõige õppija eneseteadvuse, mina-pildi, enesehinnangu ja mina-ideaali arenguga õpiprotsessis ning tingimuste loomisega nende kvaliteetide kujunemiseks. 
Arengu juhtimise, kasvatamise ja õpetamise hädavajaliku tingimusena käsitatakse eriti biheivioristlikus mõtlemisviisis teatud kasvatus- ja õpetamismeetodite kasutamist. Ka vanasõnades on see keskseks teemaks, kusjuures meetoditena on esiplaanil karistamine (s.h kehaline), käskimine, keelamine, laitmine, hirmu tekitamine; ning väga vähesel määral ka kiitmine ja n-ö armu jagamine.

Eesti kasvatusteadlastest on karistamist kui sellist käsitlenud kõige rohkem Peeter Põld (1993) 20. sajandi esimesel poolel, 21. sajandi algul aga Maie Tuulik (2001), kes on seejuures täielikult toetunud Põllu seisukohtadele. Karistamisega seoses saab eristada mitmeid teooriaid ja seisukohti. Karistus võib olla vaadeldav kui lepitus- ja tasumisabinõu, mis korvab õigusrikkuja tekitatud valu ja halva. Kahju korvamisega saab ühiskonda lepitada ja karistatule tähendab see võimalust oma südametunnistust kergendada. Kindlustusteooria esmane eesmärk on teha õigusrikkuja ühiskonnale kahjutuks, võtta võimalus pahategu korrata. Hirmutusteooria siht on anda teistele teada tagajärgedest, mida toob kaasa hukkamõistetav tegu. Kõige pedagoogilisem on parandusteooria, mis taotleb teatavaid tagajärgi karistatava enda juures. Karistus peaks andma süüalusele teadmise, et ta on teinud ülekohut, ning kutsuma temas esile häbi ja kahetsuse (Põld 1993: 98-101; Tuulik 2001: 123-124). Peeter Põllu (ibid.: 96-97) arvates vajab laps käske ja keelde, et õppida tundma ümbritsevaid piire, samas peaksid need kaasa aitama lapse arengule ja iseseisvumisele. Keelamisest parem olevat takistada, käskimisest parem juhtida. Et karistus annaks soovitud tulemuse, peaks arvestama järgmist (Põld 1993: 113-117; Tuulik 2001: 125): 1) karistatav peaks aru saama, mille eest teda karistatakse; 2) karistajale peaks olema selge, kas süütegu oli juhuslik või korduv tegevus; 3) karistusviisi valimisel tuleks arvestada individuaalsete asjaoludega, kuidas karistatav tajub karistuse suurust; 4) karistust peetakse ebaõiglaseks, kui karistaja ja karistatava vahel ei ole usalduslikku ja vastastikku austavat suhet; 5) karistus peaks tulenema karistatava teost loomuliku tagajärjena; 6) karistust ei tohiks pikalt edasi lükata, karistada tuleks viha ja ärrituseta ning pärast järelemõtlemist; 7) kui karistus on andnud tulemusi, siis peaks kohe järgnema andeksandmine ja unustamine.

Peeter Põld (1993: 107-110) nimetab kuut võimalikku karistusvormi: loomulik karistus, rahakaristus, toidukaristus, aukaristus, vabaduskaristus, kehaline karistus. Rahakaristust saab rakendada koolis, aga kui vanemad peavad midagi kinni maksma, siis on see pigem karistuseks nendele. Toidukaristus pärineb keskajast ja lähtub askeetlusest, mida saab kasutada toidu rikkujate puhul. Aukaristuse vormideks on näiteks süüalusele terava pilgu heitmine, sõnaline laitus, tavapärasest teistsuguste tingimuste määramine jne. Vabaduskaristus tähendab, et piiratakse lapse vaba aega ja ruumi näiteks karistustööde tegemise, kindlas ruumis olemise vms abil. Põllu väitel on aastasadu 
mõeldud karistusena just kehalist karistamist (vitsa, kepi, piitsa abil). Kuni kümneaastaste laste puhul võivat sellest abi olla, kui karistus ei tekita viha ega kangekaelsust. Kui laps on vanematega lähedastes suhetes, siis ei saa ka karistus neile halba mõju avaldada. Kehaline karistus on kiire viis sundida last pöörama tähelepanu soovitavale eesmärgile.

Kuna pole kindel, kas karistus täidab oma eesmärke, siis leidub palju ka karistamise vastaseid. Peeter Põld (1993: 101-103) viitab Jean-Jacques Rousseau'le, kes esimesena eitas karistamist, kuna see võib süvendada inimeses hoopis pahesid. Ta pooldas tegudest enestest tulenevat loomulikku karistust, mille puhul laps kannatab vaid oma teo selgete tagajärgede pärast. Rousseau taunis kasvatamisel selliseid sõnu nagu sõna kuulma, käskima, kohus ja kohustus. Karistus olevat võõra tahte peale surumine, mis põhineb hirmul, seetõttu ei saavat see avaldada positiivset mõju. Kehalise karistuse vastased väidavad, et ihunuhtlus teeb tuimaks, võib mõjuda tervisele halvasti ning toimida alandavalt nii peksjale kui pekstavale.

Kasvatusmeetodid peaksid võimaldama liikumist taotletava eesmärgini. Nõnda väidetakse nii eesti kasvatusteaduses kui ka vanasõnades. Johannes Käis (2018: 24) rõhutab, et kasvatuse kaudu omandatakse oma rahva kultuur, keel, kombed. Kasvatus loob identiteeti ja aitab sotsialiseeruda (vrd nt Põld 1993; H. Liimets 1998; Orn 1998; Kraav 2003). Jüri Orn (1998: 13-14) ütlebki, et kasvatust ei saa mõista üksnes kasvataja ja kasvandiku vahelise interaktsioonina, vaid kasvatus on laiemalt käsitatav kui toimiv sotsiaalne tegelikkus. Heino Liimetsa (1998: 16-18) järgi leiab kasvatus ühiskonnas aset kolmel tasandil: 1) sotsiaal-pedagoogiline tase, kus toimub vastava ühiskonna sotsiaalse struktuuri ja kultuuri taastootmine ja edasiarendamine; 2) organisatsioonilispedagoogiline tase, kus toimub kasvatussüsteemi interaktsioon inimgruppidega; 3) psühholoogilis-pedagoogiline tase, kus toimub otsene kasvataja ja kasvatatava interaktsioon. Jüri Orni (1998: 10) kombel võib öelda, et igal nimetatud tasemel kujuneb inimese väärtuseline suhe teda ümbritsevasse ja iseendasse, midagi väärtustub inimese jaoks. Seega esineb kasvatus kui väärtustamine.

See, et kasvatus vahendab ja taastoodab ühiskonnas kehtivaid väärtusi ja norme, tuleb selgelt ilmsiks ka eesti vanasõnades. Peeter Põld (1993: 20-40, 146-149) esitab tema arvates olulisimad püüeldavad väärtused hierarhiana: 1) vitaalsed, 2) tehnilis-majanduslikud, 3) tunnetuslikud, 4) esteetilised, 5) õiguslikud, 6) eetilised, 7) usulised väärtused. Religioossetest väärtustest saavad oma tähenduse ka eetilised väärtused. Usulised väärtused annavad inimesele väidetavalt julguse, kindluse, teadmise, et maksab elada ja elul on tähendus. Kristliku eetika õpetamisega saab süvendada kõlbelisi arusaamu ja voorusi ning tugevdada häid harjumusi, mistõttu ongi tõstetud kõrgeimale 
kohale usulised väärtused. Kindlatest väärtustest ja moraalinõuetest lähtuvate harjumuste kujundamist peabki Põld (ibid.: 81-90) kasvatuses väga oluliseks, kuna need tagavad stabiilsuse ja traditsioonid. Alustama peaks sealjuures väikestest asjadest ja otsima igapäevasest elust sobivaid võimalusi tahte kasvatamiseks. Maie Tuuliku (2001: 134-145) arvates ei võimalda tänapäevane väärtuste paljusus ja ambivalentsus pakkuda lapsele kasvamiseks selget ja ühest väärtuste hierarhiat.

Väärtuste kandjaks peaks Peeter Põllu (1993: 65-80) järgi eelkõige kasvatuses olema keegi autoriteetne isik kui eeskuju, ehkki autoriteedile rajanevas kasvatuses näeb Põld ka puudusi. See nivelleerib individuaalsust, soodustab passiivsust ning väärtuste kivinemist, ei arenda kriitikameelt. Soome kasvatusteadlased Sirkka Hirsjärvi ja Jouko Huttunen (2005: 53) väidavad, et autoriteedile rajatud suhted määravad kellegi kõrgema ja madalama staatuse ning vastavalt võimu kasutajad ja sellele allujad.

Sellised suhted vanemate ja laste vahel ning kasvatuses tulid ilmsiks ka vanasõnadest. Seda võiski eeldada, sest vanasõnade maailm väljendab feodaalaja Eestile iseloomulikku talupere struktuuri (vrd Vissel 2004: 8-10). Lastel oli tollal vanuse tõttu taluperes madal sotsiaalne staatus. Ühiskondlik staatus sõltus ka soost. Talupojaühiskonnas oli mees perekonna pea ja toitja, Soolisest tööjaotusest tulenevalt kasvatas lapsi peamiselt naine ja tegi seda muude tööde kõrvalt. Lapsed kasvasid vanemate kõrval, neid rakendati varakult talutöödes. Lastes kasvatati ausust, tagasihoidlikkust, virkust, hoolsust, töökust. Eelis oli poegadel: neile anti rohkem haridust ning nemad jäid tallu. Ka Peeter Põld (1993) on rõhutanud vanemate kui kasvatajate juures nende soost tingitud erinevusi ning on autoriteetsuse seostanud eelkõige isaga. Seega pidi kasvatus vanasõnade päritolukontekstis taastootma stereotüüpselt traditsioonilist rollijaotust perekonnas, mis oli iseloomulik patriarhaalsele ühiskonnale. Maailmapilt oli väärtuseliselt normatiivne ning liigendunud musta ja valge vastandumise põhimõttel, sisaldades kindlaid tõdesid selle kohta, missugune on hea ja missugune halb laps. Heaks peeti last, kes nõustus oma vanemate kasvatusviisidega ning austas vanemaid. "Austamine on alati vähema suhe suuremasse, aukartus ohjeldab. Neid, keda austatakse, võetakse ka eeskujuks," väidab Maie Tuulik (2001: 33). Tuuliku arvates peaks sellistest kindlatest suhete hierarhilisust väärtustavatest tõekspidamistest lähtuma ka tänapäeval.

Vanasõnades peituv argitarkus ning vastav argiteadvuslik maailm haakub ning kajab eesti kasvatusteaduses vastu eelkõige kahe autori ideedes ja töödes. Need on Peeter Põld ja Maie Tuulik, kes esindavad normatiivset kristlik-konservatiivset vaadet kasvatusele, mis teaduses haakub eelkõige biheivioristliku mõtlemisviisiga, kus kasvatatav on käsitatav passiivse objektina võimule ja 
autoriteedile rajanevas kasvatussuhtes. Temaatiliselt (kasvatussuhe kui fenomen, lapse areng ja selle mõjutamine, kasvatav õpetamine ja elukestev õppimine, kasvatustegevuse erinevad tasandid, ema ja isa rollid kasvatuses, kasvatamine eeskuju abil, soolisus kui fenomen kasvatuses, kasvatuseesmärgid ja -meetodid) seostuvad vanasõnad loomulikult ka teiste eesti kasvatusteadlaste eelkõige Johannes Käis, Heino Liimets, Airi Liimets, Jüri Orn, Inger Kraav, Tiiu Kuurme - mõtete ja töödega, kuid sisulistes rõhuasetustes puuduvad nendel väärtuseliselt normatiivne ning biheivioristlik maailmamõistmine. Teaduses esindatakse kognitivistlik-konstruktivistlikku ja humanistlikku ning hermeneutilis-fenomenoloogilist mõtlemist.

Vanasõnadest ilmnenud fenomenid ja teatud normatiivne mõtlemisviis on kasvatuspraktikast väga visad kaduma (nt soorollide traditsiooniline käsitlus jm) ka tänapäeval, samuti biheivioristlik mõtlemisviis üldse, mida toetab tänapäevane neoliberalistlik ideoloogia. Rahvaluuleteadlaste (nt Järv 2019) arvates pakuvad vanasõnad teatud valiku rahvatarkusest, mille seast igaüks võib kasutada seda mõtet, mida õigeks peab. Kasvatuses ootavad vanemad ja õpetajad probleemidele sageli paraku ühte ja nn õiget lahendust, vastust. Üht ja “õiget” ei leia aga ei kasvatusteadusest ega paku sellist tõde ka vanasõnad. Nii saab tänapäevalgi vanasõnadele loovalt läheneda. Seega ei ole vanasõna üksnes "vana" või lausa ajalukku kuuluv folkloorižanr. Ka tänapäeval leitakse vanasõnadest üldinimlikke universaalseid tõdesid ja luuakse tõlgendusi, mis sobivad nüüdisinimese elumaailma.

\section{Kirjandus}

Aruste, Sandra 2014. Lasteaiaõpetajate hinnangud väärtuskasvatusmetoodikale Väärtuskasvatus Tarkuse Hoidise abil. Bakalaureusetöö. Tartu: Tartu Ülikool (https://dspace. ut.ee/handle/10062/42160 - 1. juuni 2021).

Baran, Anneli 2010a. Fraseologismide rollist Eesti koolinoorte keelekasutuses 2007. aasta koolipärimuse kogumisvõistluse põhjal. Kalmre, Eda (toim). Tulnukad ja internetilapsed. Uurimusi laste- ja noortekultuurist. Tänapäeva folkloorist 8. Tartu: EKM Teaduskirjastus, lk 95-124.

Baran, Anneli 2010b. Sooline aspekt eesti fraseoloogias. Ariadne Lõng 1-2, lk 94-105.

Cowan, Karin 2019. Inglise keele õpetajate arvamused vanasõnade õpetamise kohta III kooliastmes: Magistritöö. Tartu: Tartu Ülikool (https://dspace.ut.ee/handle/10062/64985 1. juuni 2021).

Dundes, Alan 2002. Kes on rahvas? Valik ideid folkloristikast. Tallinn: Varrak.

Eisen, Matthias Johann 1993. Eesti vanasõnad. Tallinn: Perioodika. 
Geertz, Clifford 2003. Omakandi tarkus. Esseid tõlgendavast antropoloogiast. Tallinn: Varrak.

Granbom-Herranen, Liisa 2012. Vanasõnad pedagoogilises kõnes. Mäetagused 51, lk 81-100 (doi: 10.7592/MT2012.51.granbom-herranen).

Granbom-Herranen, Liisa \& Babič, Saša \& Voolaid, Piret 2015. Proverbial Expressions in Newspapers: Comparative Study in Estonia, Finland and Slovenia. Traditiones: zbornik Instituta za slovensko narodopisje in Glasbenonarodopisnega inštituta ZRC SAZU = Acta Instituti ethnographiae et Instituti ethnomusicologiae Slovenorum 44 (3), lk 5-32 (doi: 10.3986/Traditio2014440301).

Hirsjärvi, Sirkka \& Huttunen, Jouko 2005. Sissejuhatus kasvatusteadusse. Tallinn: AS Medicina.

Honko, Lauri 1998. Folklooriprotsess. Mäetagused 6, lk 56-84 (doi: 10.7592/MT1998.06. honko).

Hussar, Annika \& Krikmann, Arvo \& Sarv, Ingrid 1984. Vanasõnaraamat. Tallinn: Eesti Raamat.

Järv, Risto 1997. Tarbetarkusest argiarvamuseni, vahel vanasõnaks välja? Hiiemäe, Mall \& Oras, Janika (toim). Maa ja ilm. Pro Folkloristica V. Tartu: Eesti Kirjandusmuseum, lk 26-42 (http://www.folklore.ee/era/nt/PF5/5Jarv.htm - 1. juuni 2021).

Järv, Risto 2019. Muna on / ei ole targem kui kana: Vastuolulised vanasõnad. Keel ja Kirjandus 8-9, lk 722-727 (https://dea.digar.ee/cgi-bin/dea?a=d\&d=AKkeeljakirjand us201908.2.24 - 1. juuni 2021).

Kaimre, Edda \& Kraav, Inger 1998. Kolme põlvkonna kasvatuslikest uskumustest. Mikk, Jaan \& Kraav, Inger \& Pedastsaar, Tiia (toim). Kodu ja kool muutuvas ajas. Artiklite kogumik. Tartu: Tartu Ülikooli pedagoogika osakond, lk 131-139.

Kaimre, Edda 2000. Millest lähtume laste kasvatamisel. Kraav, Inger (toim). Kodu Eesti ühiskonnas ja kultuuris. Tartu: Perekasvatuse Instituut \& TÜ pedagoogika osakond, lk 6-11.

Kask, Kätlin 2013. Folkloori lühivormid 5. ja 6. klassi emakeele ja kirjanduse õppematerjalides. Magistritöö. Tartu: Tartu Ülikool.

Kraav, Inger 2003. Lapse heaolu ja lapsevanema ootused ühiskonnale. Kraav, Inger (toim). Kodukasvatus ja ühiskond. Tartu: Perekasvatuse Instituut, lk 12-35.

Krikmann, Arvo 1997. Sissevaateid folkloori lühivormidesse I. Põhimõisteid, žanrisuhteid, üldprobleeme. Tartu: Tartu Ülikooli Kirjastus.

Krikmann, Arvo 2002. Ütluste semantikast. Tartu: Tartu Kirjandusmuuseum (http:// www.folklore.ee/ kriku/RETSEM/ - 1. juuni 2021).

Krikmann, Arvo \& Sarv, Ingrid (toim) 1980-1988. Eesti vanasõnad I-V. Tallinn: Tallinna Pedagoogikaülikooli kirjastus.

Kuurme, Tiiu 2003. Kasvatuse võim ja võimetus. Valitud esseed kasvatusest. Tallinn: Tallinna Pedagoogikaülikooli kirjastus. 
Kõiv, Helene 2011. Vanasõnade kasutamine inglise keele kui võõrkeele osaoskuste õpetamisel ja väärtustest kõnelemisel II kooliastmes. Bakalaureusetöö. Tartu: Tartu Ülikool (https://dspace.ut.ee/handle/10062/18014 - 1. juuni 2021).

Käis, Johannes 2018. Õpetuse alused ja teed. Üldine didaktika. Tartu: Studium.

Lagerspetz, Mikko 2017. Ühiskonna uurimise meetodid. Sissejuhatus ja väljajuhatus. Tallinn: TLÜ Kirjastus.

Laherand, Meri-Liis 2008. Kvalitatiivne uurimisviis. Tallinn: Meri-Liis Laherand.

Liimets, Airi 1999. Käsitused kasvatusest eesti kasvatusteaduslikus mõtlemises. Utno, Leili (koost). IV Välis-Eesti kongress 29.-30. juunil 1999. aastal Tallinnas: Ettekannete kokkuvôtted. Tallinn: Välis-Eesti Ühing, lk 23-24.

Liimets, Airi 2009. (Muusika)kasvatus kui inimese ja olemise diferents. Liimets, Airi (koost ja toim). Muusikalise kontegelikkuse ühendused identiteedi ja diferentsiga. Tallinn: Tallinna Ülikool, lk 385-396.

Liimets, Airi \& Koit, Marit 2018. Miks kuulata muusikat ja vaikust? Mäetagused 72 , lk 23-48 (DOI: 10.7592/MT2018.72.liimets_koit).

Liimets, Heino (koost ja toim) 1974. Pedagoogika õpik ülikoolidele (käsikiri). Tartu: Tartu Riiklik Ülikool.

Liimets, Heino 1985. Noore õpetaja didaktilised probleemid. Virkus, Rein (koost). Noorele õpetajale [Klassi sotsiaalpsühholoogia, õpetajapsühholoogia, didaktikast ja õpilaste tervisekasvatusest]. Tallinn: Valgus, lk 8-46.

Liimets, Heino 1998. Kuidas õppeprotsess kasvatab? Liimets, Airi (toim) \& Laherand, Meri-Liis (tõlkinud). Tallinn: Tallinna Pedagoogikaülikooli Kirjastus.

Loorits, Oskar 1951. Eestluse elujõud. Stockholm: Tõrvik.

Mieder, Wolfgang 2004. Proverbs: A Handbook. London: Greenwood Press.

Mitt, Merike 2012. Väärtuskasvatus Tarkuste Hoidise abil. Eesti rahvapärimusel põhinev metoodika lasteaedadele, algkoolidele ja lapsevanematele. Tartu: MTÜ Väärtuskoolitus.

Normann, Erna (koost) 1955. Valimik eesti vanasõnu. Tallinn: Eesti Riiklik Kirjastus.

Orn, Jüri 1998. Meie kasvatustegelikkuse väärtusest. Kuurme, Tiiu \& Laherand, MeriLiis (toim). Õpetaja ja õpilane kasvatustegelikkuses. Tallinn: Tallinna Pedagoogikaülikool, lk 9-43.

Palacios, Jesús López 1996. Proverbs as a Images of Children and Childrearing. Hwang, C. Philip \& Lamb, Michael E. \& Sigel, Irving E. (toim). Images of Childhood. Mahwah, NJ: Lawrence Erlbaum Associates, lk 75-98.

Põld, Peeter 1993. Üldine kasvatusõpetus. Tartu: Tartu Ülikool.

Pärismaa, Sirje 2018. Kas kiitus ongi vaid lollide lõks? Õpetajate Leht 8.06.2018 (https:// opleht.ee/2018/06/kas-kiitus-ongi-vaid-lollide-loks/ - 2. juuni 2021).

Schreier, Margrit 2012. Qualitative Content Analysis in Practice. London: Sage. 
Stanciu, Dumitru 1986. The Proverbs and the Problems of Education. Proverbium 3, lk 153-178.

Taylor, Archer 1931. The Proverb. Cambridge, Massachusetts: Harvard University Press.

Teras, Ene 2019. Hoolivuse- ja sõpruse-teemaliste vanasõnade mõistmine 6-7-aastastel lastel. Magistritöö. Tartu: Tartu Ülikool (https://dspace.ut.ee/handle/10062/65150 2. juuni 2021).

Tilk, Maria 2000. Kodukeel. Kraav, Inger (toim). Kodu Eesti ühiskonnas ja kultuuris. Tartu: Perekasvatuse Instituut \& TÜ pedagoogika osakond, lk 93-102.

Tuulik, Maie 2001. Kasvatusõpetus. Tallinn: Riiklik Eksami- ja Kvalifikatsioonikeskus.

Vainik, Ene 2016. Eesti tunded. Sõnaportreed. Tallinn: Eesti Keele Sihtasutus.

Vissel, Anu 2004. Lastepärimus muutuvas ühiskonnas. Tartu: Eesti Kirjandusmuuseum.

Volkov, Gennadi = Volkov, Genadi N. 1999. Etnopedagogika. Moskva: Izdatel'skii tsentr Akademiia.

Voolaid, Piret 2011. Üle-eestilise lasteaiapärimuse kogumisvõistluse lühikokkuvõte. Eesti Kirjandusmuuseumi folkloristika osakonna kodulehekülg folklore.ee (http:// folklore.ee/kp/lp/v6it.htm - 2. juuni 2021).

Voolaid, Piret 2020. Parem üks nädal liiga kaua kui üks päev liiga vähe ehk Vanasõnad kui sõnumi edastamise võimsad vahendid ametlikus ja rohujuuretasandi kriisisuhtluses. Sirp 8. mai, lk 18-19 (https://www.sirp.ee/s1-artiklid/c21-teadus/parem-uks-nadal-liigakaua-kui-uks-paev-liiga-vahe-ehk/ - 2. juuni 2021).

\title{
Summary
}

\section{Conceptions of education in Estonian proverbs and educational science}

\author{
Bianka Makoid \\ Head of the Department of Education and Culture \\ Education and Youth Work Specialist \\ Peipsiääre Rural Municipality Government \\ bianka.makoid@peipsivald.ee
}

\author{
Airi Liimets \\ Visiting Professor of Philosophy of Education \\ School of Educational Sciences, Tallinn University \\ airi_liimets@yahoo.de
}

Keywords: conceptions of education, Estonia, proverbs, qualitative content analysis, educational thought, comparison of everyday conscious and scientific 
In this article, we have set ourselves a goal to identify how the conceptions of education contained in Estonian proverbs coincide with the corresponding educational thought in Estonia. We have empirically studied 655 Estonian proverbs that directly refer to a child, growing up, upbringing and parents as well as the methods of education. In the empirical research, we look at whether and how it is possible to semantically categorize and define proverbs based on the educational meanings in their content. To have a clearer system for analysis, we created a comprehensive scheme of categories. The four main categories with subcategories formed during the work.

As can be concluded from the analysis of proverbs, the everyday wisdom that lies in them mostly coincides with behaviouristic conceptions of education as interaction and development management. According to educational scientist Heino Liimets, the interaction becomes truly mutual, but only at the highest level of acceptance of the educator's influence - internal acceptance or interiorization. At lower levels, i.e., only agreeing to or external identification of influence, this is an influence from the educator's position of power where the educable is passive, subordinate, and obeys commands. This content is characterized by behaviouristic thinking in educational science and can also be observed in proverbs.

Behaviouristic beliefs also address the need of the proverbs to take into account the peculiarity of a child in their upbringing, which mainly mean the timeliness of education, i.e., a person can be forced into something only in childhood and youth. Upbringing, education, and learning/teaching are considered practically as synonyms in proverbs and behaviouristic educational science, both being regarded as the management of development from outside a human being.

The use of certain educational methods, upbringing, and teaching methods is considered an essential condition for the management of development, education, and teaching, especially in behaviouristic thinking in science. It is a central theme also in proverbs where punishment (incl. physical), ordering, forbidding, disapproving, and causing fear are at the forefront as methods, and praising and "sharing mercy" can be found only to a very limited extent.

To speak about Estonian educational scientists, Peeter Põld dealt with the topic of punishment mainly in the first half of the 20th century and Maie Tuulik at the beginning of the 21st century; the latter, however, has completely relied on the ideas of Põld. J. Käis emphasises that the culture, language, and customs of one's nation are obtained by means of education. Education creates identity and helps socialize. Thus, education occurs as a valuation.

The fact that education mediates and reproduces the values and norms valid in society is also clearly evident in Estonian proverbs. In the opinion of Maie Tuulik, modern diversity and ambivalence of values do not allow one clear hierarchy of values to be offered to a child to grow up. According to Põld, the bearer of values should primarily be someone authoritative as an example of education, although Põld himself also sees shortcomings of education based on authority. It levels individuality, promotes passivity and creates conventional values; it does not develop a sense of criticism. The relationships built on authority determine the higher and lower status of someone and, accordingly, the users of and subordinates to the power. 
Such relationships between parents and children as well as in education appear also in proverbs, which is expected because the world of proverbs expresses the structure of a peasant family characteristic of feudal Estonia. Due to their age, children had a low social status in the family at that time. Social status also depended on the gender. In peasant society, man was the head and provider for the family. Sons had an advantage over daughters: they were given more education and they stayed at the farm. Põld has also associated authority primarily with the father. Thus, education had to reproduce the stereotypically traditional division of roles in a family, which was characteristic of the patriarchal society. The worldview was value-based and normative and divided according to the principle of black and white, containing firm truths about who is a good and who is a bad child. A child who agreed to the upbringing of his/her parents and who respected the parents was considered good. According to Tuulik, such firm beliefs that value the hierarchical nature of relationships should be based on also today.

Thus, everyday wisdom and corresponding everyday conscious world found in proverbs is present and reflected in Estonian educational science, especially in the ideas and works of two authors. These are Peeter Põld and Maie Tuulik, who represent a normative Christian-conservative view of upbringing and education, which in science is primarily related to the behaviouristic way of thinking, in which the educable is regarded as a passive object in a relationship of education based on power and authority. Thematically, of course, proverbs are also associated with the thoughts and works of other Estonian educational scientists - in particular, J. Käis, H. Liimets, A. Liimets, J. Orn, and I. Kraav, but in substantive emphasis these scientists represent a cognitiveconstructivist, humanistic and hermeneutic-phenomenological way of thinking.

Bianka Makoid on Peipsiääre vallavalitsuse haridus- ja kultuuriosakonna juhataja, haridus- ja noorsootöö spetsialist; kasvatusteaduste magister (2020, Tallinna Ülikool).

Bianka Makoid (MA in Educational Science, Tallinn University 2020) is Head of the Department of Education and Culture of Peipsiääre Rural Municipality Government and Education and Youth Work Specialist.

bianka.makoid@peipsivald.ee

Airi Liimets on Tallinna Ülikooli kasvatusfilosoofia külalisprofessor; Eesti Muusika- ja Teatriakadeemia doktorikooli ja lavakunstikooli külalisprofessor; kasvatusteaduse doktor (Dr. paed) kasvatusfilosoofia alal (2004, Heidelbergi Pedagoogikaülikool). Peamised uurimisvaldkonnad: filosoofiline ja pedagoogiline antropoloogia, kasvatusfilosoofia, noorsoosotsioloogia, üldkasvatusteadus. 
Airi Liimets ( $\mathrm{PhD}$ in philosophy of education, Heidelberg University of Education 2004) is visiting professor of philosophy of education at Tallinn University and visiting professor at the doctoral school and at the school of drama at the Estonian Academy of Music and Theatre. Her main fields of research involve philosophical and pedagogical anthropology, philosophy of education, sociology of youth, and general educational science.

airi_liimets@yahoo.de 